\title{
UNDERSTANDING AGRICULTURAL VIRTUAL WATER FLOWS IN THE WORLD FROM AN ECONOMIC PERSPECTIVE, A LONG TERM STUDY
}

Rosa Duarte ${ }^{+* * *}$, Vicente Pinilla ${ }^{++}$and Ana Serrano ${ }^{+++}$

+ Universidad de Zaragoza, Department of Economic Analysis, Faculty of Economics and Business Studies and Instituto Agroalimentario de Aragón (IA2), Gran Vía 2, 50005 Zaragoza, Spain, rduarte@unizar.es

++ Universidad de Zaragoza, Department of Applied Economics and Economic History, Faculty of Economics and Business Studies and Instituto Agroalimentario de Aragón (IA2), Gran Vía 2, 50005 Zaragoza, Spain, vpinilla@unizar.es

${ }^{+++}$Universitat de Girona, Department of Economics, Faculty of Economics and Business Studies, Carrer de la Universitat de Girona 10, 17002 Girona, Spain, ana.serrano@udg.edu

Abstract: The globalization process of the last half century entailed a growing trade in agricultural and food products. As a result, water has been transferred among countries, embodied in these goods. This paper studies the evolution of virtual water flows over the long term, analyzing the main driving factors through Decomposition Analysis. It contributes to the existing literature by offering a dynamic and economic interpretation of the historical changes in virtual water trade flows. In particular, this study points to a gradual increase in virtual water exchange, related to the upsurge of agricultural and food products trade in the world from 1965 to 2010. Although the origins and destinations of virtual water have changed, North America stands out as the primary net exporter of virtual water. Europe and Asia, on the other hand, with a high dependency on foreign water resources, appear as net importers of virtual water. Despite improvements in agricultural yields and the reallocation of production, the virtual water trade continues to increase globally via these significant commercial exchanges.

Keywords: virtual water trade, water consumption, globalization and environment

\footnotetext{
*** University of Zaragoza, Department of Economic Analysis, Faculty of Economics and Business Studies, Gran Vía 2, 50005 Zaragoza, Spain, rduarte@unizar.es
} 


\section{Introduction}

Food production has experienced a marked increase during the last fifty years (Federico, 2005; Rask and Rask, 2011). Alongside this expansion, commercial exchanges of agricultural and food products have experienced significant growth in the past half century (Serrano and Pinilla, 2010, 2011a). This globalizing process has involved not only an important trade in commodities, but also very large exchanges of the natural resources embodied in these goods (Schmitz et al., 2012).

This is certainly the case for embodied water, which has been growing strongly in the products of international trade. A large number of studies have been carried out over the last decade (Clark et al., 2015; Duarte et al., 2014b; Hoekstra and Hung, 2005; Tamea et al., 2014) to examine the displacement of water resources resulting from the growing integration of global economies. In this framework, virtual water, first defined by Allan (1997), is the volume of water necessary for the production of a commodity. The water footprint is an indicator of freshwater use that looks at both direct and indirect water use of a consumer or producer (Hoekstra et al., 2011). The studies of virtual water and the water footprint distinguish between green and blue water; according to Hoekstra and Chapagain (2008), green water is the rainwater evaporated as a result of the production of a commodity, and blue water is surface or groundwater evaporated during a production process. Both are interrelated in the hydrological system, but blue water has higher opportunity costs, as it can be reallocated among the different users (Yang et al., 2007). Virtual water has been methodologically studied from the top-down and bottom-up approaches. The former adopts environmental input-output analysis to obtain virtual water and water footprints by accounting for regional, national and/or global supply chains (Cazcarro et al., 2013; Deng et al., 2015; Duarte et al., 2015b; Feng et al., 2012; Steen-Olsen et al., 2012; Yu et al., 2010). The latter obtains footprints on the basis of the virtual water content of internationally traded goods and services determined from detailed process data (Duarte et al., 2014a, c, 2015a; Hoekstra and Hung, 2005; Hoekstra and Mekonnen, 2012; Vanham et al., 2013). In this paper, we will use the bottom-up methodology that, according to Feng et al. (2011), "has become one of the most popular approaches in water footprinting studies due to its simplicity and 
relatively good data availability". It allows us to study global virtual water flows of agricultural and food products in a highly disaggregated way.

Whereas many of these studies focus on the short term, to our knowledge there are few papers empirically addressing global virtual water trade flows over the long run (Clark et al., 2015; Tamea et al., 2014). From our viewpoint, the long-term approach is essential to assess the relationship between economic growth and natural resources, addressing the historical trajectories and feedbacks. This seems particularly important in the period studied, when the second wave of globalization took place. This long-term process has entailed an outstanding economic and commercial integration that has resulted in growing exchanges of factors and products that embody large volumes of water. The analysis of the environmental implications of globalization processes in the long term, from an economic perspective, is in our view one of the main contributions and innovations of our study. The broad sample considered, including a large number of products and countries, is another of the strong points of the paper. The high level of disaggregation allows us to go deeper into the explanation of virtual water trade in the long run. It is important to highlight that we estimate virtual water trade flows for a long period, but we also explain and quantify the factors behind these trends using an economic approach.

Thus, this paper assesses the trends in virtual water transfers in the world from 1965 to 2010, a period of intense internationalization that led to important environmental impacts. To that end, we analyze global trends paying special attention to those areas that exert the largest pressures on those domestic water resources that are exported, studying the amount and direction of global virtual water flows. We obtain and quantify those factors, driving the path followed by virtual water imports and exports. By means of a Decomposition Analysis (DA), trends in water exchanges are explained on the basis of changes in the volume of trade, in the product-trade composition, in the origin of flows, and in the main commercial countries dealing with agricultural and food products. DA has been utilized in other studies that explain the determinants of changes in virtual water trade flows (Duarte et al., 2014a, c; Kondo, 2005). 
The intended contribution of the paper is the analysis of the effects that economic integration, trade expansion, specialization patterns, etc. and the historical factors occurring in the world, have had on the environment, from a long-term perspective, and particularly on an indicator of water pressures. Hence, this study is concerned with the relationship between globalization and natural resources, through the case study of water. To our knowledge, hitherto, water resources have been primarily analyzed from a short-term perspective, while we contribute to the scarce existing literature on virtual water trade flows in the long run (Clark et al., 2015), offering an analysis of the pressures on global water resources from an economic perspective. Our work builds on the prior literature describing water embodied in production and trade (Hoekstra and Chapagain, 2008; Hoekstra and Hung, 2005; Zhan-Ming and Chen, 2013).

The following Section addresses the main methodological aspects and explains the data, Section 3 deals with the main findings of our work, Section 4 contains a discussion of the results, and Section 5 presents our main conclusions.

\section{Materials and methods}

\subsection{Methodological aspects}

As a first step, we estimate virtual water trade flows following the methodology proposed by Hoekstra and Hung (2005). For a country $c$ in year $t$ virtual water exports $\operatorname{VWX}(c, t)$ can be obtained as:

$$
V W X(c, t)=\sum_{p} d_{p}^{c}(c, p, t) x_{p}^{c}(c, p, t)
$$

With $x_{p}^{c}$ being the quantity of product $p$ exported (Tonnes) and $d_{p}^{c}$ a coefficient indicating the volume of water necessary to produce a tonne of each commodity in the exporting country, i.e., water footprint ( $\mathrm{m}^{3} /$ Tonne). $d_{p}^{c}$ will distinguish between green or blue water.

For a country $c$, virtual water imports are the sum of the water embodied in the imported goods coming from all countries $z$.

$$
V W M(c, t)=\sum_{p z} d_{p}^{Z}(z, p, t) m_{p}^{z}(z, p, t)
$$


With $m_{p}^{Z}$ being the bilateral import flow from country $z$ to country $c$ (Tonnes) and $d_{p}^{Z}$ representing the water required in country $z$ to produce $p\left(\mathrm{~m}^{3} /\right.$ Tonne). Calculating the difference between virtual water exports and virtual water imports, we get the virtual water trade balance for each country c, as in Hoekstra et al. (2011):

$$
V W B(c, t)=V W X(c, t)-V W M(c, t)
$$

Second, we apply a Decomposition Analysis (DA) to obtain the factors driving virtual water export and import changes in the world, following the approach applied by Duarte et al. $(2014 a, c)$ for the case study of Spain . Embodied water in exports can be explained on the basis of four elements, obtaining:

$$
V W X(c, t)=\sum_{p} w_{c p t} \frac{x_{c p t}}{x_{c t}} \frac{x_{c t}}{x_{t}} x_{t}
$$

The former expression, for country $c$ can be obtained as follows:

$$
V W X(c, t)=\mathbf{w}_{\mathbf{c t}}^{\prime} \boldsymbol{X}_{\mathbf{c t}} s_{\mathrm{ct}} x_{t}
$$

With $\mathbf{w}_{\mathbf{c t}}^{\prime}$ being a row vector of the water footprint per $\$$ of product in $\mathrm{m}^{3} / \$$ (US dollars) in country $c, \mathbf{X}_{c t}$ is a vector showing the share that each product represents in total exports of country $c$ in period $t$ (product composition of the trade flow). $s_{c t}$ is a scalar with the percentage of the country in total exports (country shares) and $x_{t}$ is the total value of exports in the world in year $t$ in US dollars (scale). Note that to be able to aggregate trade flows in the DA it is necessary to express the water footprints in $\mathrm{m}^{3} / \$$ instead of $\mathrm{m}^{3} /$ tonne.

For the whole world economy:

$$
V W X(t)=\mathbf{w}_{\mathbf{t}}^{\prime} \boldsymbol{X}_{\mathbf{t}} \boldsymbol{s}_{\mathrm{t}} x_{t}
$$

With $\mathbf{w}_{\mathbf{t}}^{\prime}$ being a vector of water footprints per product and country, $\boldsymbol{X}_{\mathbf{t}}$ a matrix of the share of product exports per country, $\boldsymbol{s}_{\mathrm{t}}$ a vector showing the country shares in total world exports, and $x_{t}$ the total volume of world exports. 
Regarding imports, virtual water imports can be explained on the basis of five drivers: product water footprints, the origin of flows, product composition of the trade flow, country shares, and the scale of trade.

$$
V W M(c, t)=\sum_{p, z} w_{c p z t} \frac{m_{c p z t}}{m_{c p t}} \frac{m_{c p t}}{m_{c t}} \frac{m_{c t}}{m_{t}} m_{t}
$$

or, in matrix form,

$$
V W M(c, t)=\mathbf{w}_{\mathbf{c z t}}^{\prime} \mathbf{M}_{\mathbf{c z t}} \mathbf{m}_{\mathbf{c t}} r_{c t} m_{t}
$$

with $\mathbf{w}_{\mathbf{c z t}}^{\prime}$ being a row vector of the embodied water per product in each of the countries $z$, from which country c imported, measured in $\mathrm{m}^{3} / \$$ (US dollars). $\mathbf{M}_{\mathbf{c z t}}$ is a matrix that includes, for each product $p$, the percentage bought by $c$ from each country $z$. $\mathbf{m}_{\mathbf{c t}}$ is a vector of product import composition in country c (with information on the share of each product in imports), $r_{c t}$ is a scalar showing the participation of country $c$ in global imports, and $m_{t}$ is a scalar with the total value of global imports in year $t$ (in US dollars).

Similarly, for the global economy, the total volume of water imports can be expressed as follows:

$$
\operatorname{VWM}(t)=\mathbf{w}_{\mathbf{t}}^{\prime} \mathbf{M}_{\mathbf{t}} \mathbf{P}_{\mathbf{t}} \mathbf{r}_{t} m_{t}
$$

With $\mathbf{w}_{\mathbf{t}}^{\prime}$ being a vector of water footprints per product and country, $\mathbf{M}_{\mathbf{t}}$ a matrix of the share of imports (per country of origin and per product, with main diagonal blocks equal to zero), $\mathbf{P}_{\mathbf{t}}$ a matrix of product composition of imports (for each country), $\mathbf{r}_{t}$ a vector of import country shares in total world imports, and $m_{t}$ the total volume of world imports.

Note that while $\operatorname{VWX}(c, t)$ differ from $\operatorname{VWM}(c, t)$ at the country level, $V W X(t)=V W M(t)$ holds for the global economy, so that aggregated water balance is zero from this perspective. The above equations can be handled at the country or at the global level. Similarly, it is possible to derive these expressions for each product considered in the sample, on the basis of the above developments.

Departing from equations (5) and (8), we utilize the DA. This approach separates a time trend of an aggregated variable into a group of driving forces that can act as accelerators 
or retardants (Dietzenbacher and Los, 1998; Hoekstra and van den Bergh, 2002; Lenzen et al., 2001). In our case, decomposition is based on five factors for imports and four factors for exports; thus, it is possible to obtain 5! and 4! exact decompositions respectively. As a "commitment solution", the average of two polar solutions is considered (Dietzenbacher and Los, 1998). Taking the average of the polar decompositions for exports we get:

$$
\begin{aligned}
\Delta V W X(c)= & \frac{\Delta \mathbf{w}_{\mathbf{c}}^{\prime} \widehat{\mathbf{X}}_{\mathbf{c t}} \widehat{\mathbf{X}}_{\mathbf{t}} x_{t}+\Delta \mathbf{w}_{\mathbf{c}}^{\prime} \widehat{\mathbf{X}}_{\mathbf{c t}-\mathbf{1}} \widehat{\mathbf{X}}_{\mathbf{t}-\mathbf{1}} x_{t-1}}{2}+\frac{\mathbf{w}_{\mathbf{c t}-\mathbf{1}}^{\prime} \Delta \widehat{\mathbf{X}}_{\mathbf{c}} \widehat{\mathbf{X}}_{\mathbf{t}} x_{t}+\mathbf{w}_{\mathbf{c t}}^{\prime} \Delta \widehat{\mathbf{X}}_{\mathbf{c}} \widehat{\mathbf{X}}_{\mathbf{t}-\mathbf{1}} x_{t-1}}{2} \\
& +\frac{\mathbf{w}_{\mathbf{c t}-\mathbf{1}}^{\prime} \widehat{\mathbf{X}}_{\mathbf{c t}-\mathbf{1}} \Delta \widehat{\mathbf{X}} x_{t}+\mathbf{w}_{\mathbf{c t}}^{\prime} \widehat{\mathbf{X}}_{\mathbf{c t}} \Delta \widehat{\mathbf{X}} x_{t-1}}{2} \\
& +\frac{\mathbf{w}_{\mathbf{c t}-\mathbf{1}}^{\prime} \widehat{\mathbf{X}}_{\mathbf{c t}-\mathbf{1}} \widehat{\mathbf{X}}_{\mathbf{t}-\mathbf{1}} \Delta x+\mathbf{w}_{\mathbf{c t}}^{\prime} \widehat{\mathbf{X}}_{\mathbf{c t}} \widehat{\mathbf{X}}_{\mathbf{t}} \Delta x}{2} \\
& =\mathrm{IE}_{x}+\mathrm{CE}_{x}+\mathrm{TSE}_{x}+\mathrm{SE}_{x}
\end{aligned}
$$

Similarly for imports we obtain:

$$
\begin{aligned}
\Delta \operatorname{VWM}(\mathrm{c})= & \frac{\Delta \mathbf{w}_{\mathbf{c z}}^{\prime} \mathbf{M}_{\mathbf{c z t}-\mathbf{1}} \widehat{\mathbf{M}}_{\mathbf{c t}-\mathbf{1}} \widehat{\mathbf{M}}_{\mathbf{t}-\mathbf{1}} m_{t-1}+\Delta \mathbf{w}_{\mathbf{c z}}^{\prime} \mathbf{M}_{\mathbf{c z t}} \widehat{\mathbf{M}}_{\mathbf{c t}} \widehat{\mathbf{M}}_{\mathbf{t}} m_{t}}{2} \\
& +\frac{\mathbf{w}_{\mathbf{c z t}}^{\prime} \Delta \mathbf{M}_{\mathbf{c z}} \widehat{\mathbf{M}}_{\mathbf{c t}-\mathbf{1}} \widehat{\mathbf{M}}_{\mathbf{t}-\mathbf{1}} m_{t-1}+\mathbf{w}_{\mathbf{c z t}-\mathbf{1}}^{\prime} \Delta \mathbf{M}_{\mathbf{c z}} \widehat{\mathbf{M}}_{\mathbf{c t}} \widehat{\mathbf{M}}_{\mathbf{t}} m_{t}}{2} \\
& +\frac{\mathbf{w}_{\mathbf{c z t}}^{\prime} \mathbf{M}_{\mathbf{c z t}} \Delta \widehat{\mathbf{M}}_{\mathbf{c}} \widehat{\mathbf{M}}_{\mathbf{t}-\mathbf{1}} m_{t-1}+\mathbf{w}_{\mathbf{c z t}-\mathbf{1}}^{\prime} \mathbf{M}_{\mathbf{c z t}-\mathbf{1}} \Delta \widehat{\mathbf{M}}_{\mathbf{c}} \widehat{\mathbf{M}}_{\mathbf{t}} m_{t}}{2} \\
& +\frac{\mathbf{w}_{\mathbf{c z t}}^{\prime} \mathbf{M}_{\mathbf{c z t}} \widehat{\mathbf{M}}_{\mathbf{c t}} \Delta \widehat{\mathbf{M}} m_{t-1}+\mathbf{w}_{\mathbf{c z t}-\mathbf{1}}^{\prime} \mathbf{M}_{\mathbf{c z t}-\mathbf{1}} \widehat{\mathbf{M}}_{\mathbf{c t}-\mathbf{1}} \Delta \widehat{\mathbf{M}} m_{t}}{2} \\
& +\frac{\mathbf{w}_{\mathbf{c z t}}^{\prime} \mathbf{M}_{\mathbf{c z t}} \widehat{\mathbf{M}}_{\mathbf{c t}} \widehat{\mathbf{M}}_{\mathbf{t}} \Delta m+\mathbf{w}_{\mathbf{c z t}-\mathbf{1}}^{\prime} \mathbf{M}_{\mathbf{c z t}-\mathbf{1}} \widehat{\mathbf{M}}_{\mathbf{c t}-\mathbf{1}} \widehat{\mathbf{M}}_{\mathbf{t}-\mathbf{1}} \Delta m}{2} \\
& =\mathrm{IE}_{m}+\mathrm{LE} E_{m}+\mathrm{CE}_{m}+\mathrm{TSE}_{m}+\mathrm{SE}_{m}
\end{aligned}
$$

Accordingly, we can explain the change in virtual water exports and imports on the basis of the scale effect (SE), which quantifies how much of the change in virtual water flows is explained by changes in the volume of exports or imports. The composition effect (CE) measures the impact of changes in the product composition of trade flows of countries in virtual water exports and imports. The trade share effect (TSE) quantifies the contribution that variations in the weight of countries in global trade have on virtual 
water trends. The localization effect (LE) indicates to what extent changes in the origin of products affect virtual water flows (it only exists for virtual water imports). Finally the intensity effect (IE), identifies the contribution of changes in product water footprints to changes in virtual water trade flows. Similar effects can be obtained at the global level on the basis of the equations above.

\subsection{Data}

Bilateral trade data on agricultural and food products are taken from United Nations Statistics Division (UN, 2013) at the four-digit level of the Standard International Trade Classification, SITC, Revision 1. We work with annual trade data from 1965 to 2010, i.e., we have 46 time steps. Our sample considers 133 products and 77 countries, accounting for approximately $85 \%$ of all agricultural and food commercial exchange in the world during those years. The full list of countries and products covered are shown in the supplementary information (SI).

Since DA requires trade data in monetary units, we calculate the global prices of each product in 1985 and express trade data at constant 1985 dollars. We use Population data from WorldBank (2014) for the years 1965, 1980 and 2000. Water availability and withdrawal data for 1965, 1980 and 2000 are taken from from FAO (2014).

The product water footprints come from Mekonnen and Hoekstra (2011, 2012), who estimate water footprints following the approach developed by Allen et al. (1998) and Hoekstra et al. (2011). As the virtual water trade flows are obtained from published data on trade and water, some uncertainties could arise. As Hoekstra et al. (2011) pointed out, these uncertainties should be taken into account. In recent years, several studies have examined some of the variables generating uncertainty in the water footprint assessment, such as evapotranspiration, rainfall, crop coefficients, maximum yield, etc. (Bocchiola et al., 2013; Guieysse et al., 2013; Zhuo et al., 2014). Note that there are alternative studies quantifying the water consumption in agriculture, such as Siebert and Döll (2010), Schmitz et al. (2013), among others. Nevertheless, we choose to use the data from Mekonnen and Hoekstra (2011, 2012), given the large sample of agricultural products and countries covered, which allows us to study the environmental impact of globalization processes from an economic perspective. 
Chenoweth et al. (2014) indicate there is no consensus regarding the methodological approach to calculating water footprints when working with cross-sectional data, particularly when dealing with time series data. In this line, Haberl et al. (2001) point out the difficulties involved in estimating environmental footprints in the long term. For the particular case of water, whereas some studies assume product water footprints to be constant over time (Renault, 2002; Shi et al., 2014), there are pioneering approaches that calculate variable water coefficients for different crops (Rockström, 2003; Rockström et al., 2007). In an attempt to capture the changes in the variables influencing the water footprint of crops and animal products ( $\mathrm{m}^{3} /$ tonne) between 1965 and 2010 (improvements in irrigation techniques, variations in the crop mix, or the growing use of fertilizers and pesticides), we calculate the long-term variable water footprints of products considering historical yield changes. To that end, we follow the approach proposed by Doorenbos and Kassam (1986) and recently applied by Dalin et al. (2012), Konar et al. (2013), Cazcarro et al. (2015):

$$
w_{c p t}=w_{c p} \frac{Y_{c p}}{Y_{c p t}}
$$

With $w_{c p t}$ being the water footprint (we distinguish the green and blue water footprint) for each product in the period of analysis, expressed in $\mathrm{m}^{3} /$ tonne, and $\mathrm{w}_{\mathrm{cp}}$ is the crop or livestock water footprint (differentiating between green and blue water) given by Mekonnen and Hoekstra $(2011,2012)$ in $\mathrm{m}^{3} /$ tonne. $Y_{c p}$ represents the average yield of the reference period (1996-2005) measured in tonnes/ha, and $Y_{c p t}$ are the annual product yields for each specific year studied, also in tonnes/ha. Data on crop and livestock yields from 1965 to 2010 are taken from the Food and Agriculture Organisation of the United Nations (FAO, 2013), giving us the average yield of rainfed and irrigated agriculture.

Equation 12 shows a decreasing, convex with respect to the origin, and hyperbolic relationship between the product water footprint and its yield, indicating that the water footprint of each good falls as its crop yield rises, showing a non-linear relationship (see Duarte et al. (2015a) for a more detailed discussion). The hypothesis underlying this approach is that long-term developments influence crop and livestock yields, and also 
affect the water footprints of products. In our view, calculating time series for the water footprint of products is important in accounting for the trends in virtual water exchanges. Keeping water footprints constant would involve assuming that agricultural management remained invariable from 1965 to 2010, which would ignore the developments introduced after the Green Revolution.

\section{Results}

\subsection{Global virtual water flows assessment}

From 1965 to 2010, the volume of water embodied in agricultural and livestock products traded went from $403 \mathrm{~km}^{3}$ in 1965 to 1,415 km³ in 2010, growing at an average annual rate of $2.7 \%$. This increase was particularly intense from 1980 on, particularly during the 1990s, when global virtual water trade flows rose by $3.8 \%$ yearly on average. This growing dependence of countries on foreign water resources from 1965 to 2010 has been observed by Clark et al. (2015). As Figure 1 shows, green water was the most important component in total virtual water, since blue water only represented $8 \%$ of global water consumption, on average. Exchanges of green water depicted the most vigorous increase, growing at $2.8 \%$ every year, compared to blue water that rose at $2.2 \%$ annually.

This growing pattern was similar all over the world, with the exception of Africa and the former Soviet Union, where the trajectory was quite erratic. The latter had a very limited participation in international trade, given its centrally-planned economy. The successor republics were quickly opened after the collapse of communism.

Figure 1: Global virtual water flows, 1965-2010 $\left(\mathrm{km}^{3}\right)$. Green water is shown on the left axis, and blue water on the right. Source: own elaboration using trade data from United Nations Statistics Division (UN, 2013) and water footprints from Mekonnen and Hoekstra $(2011,2012)$. 


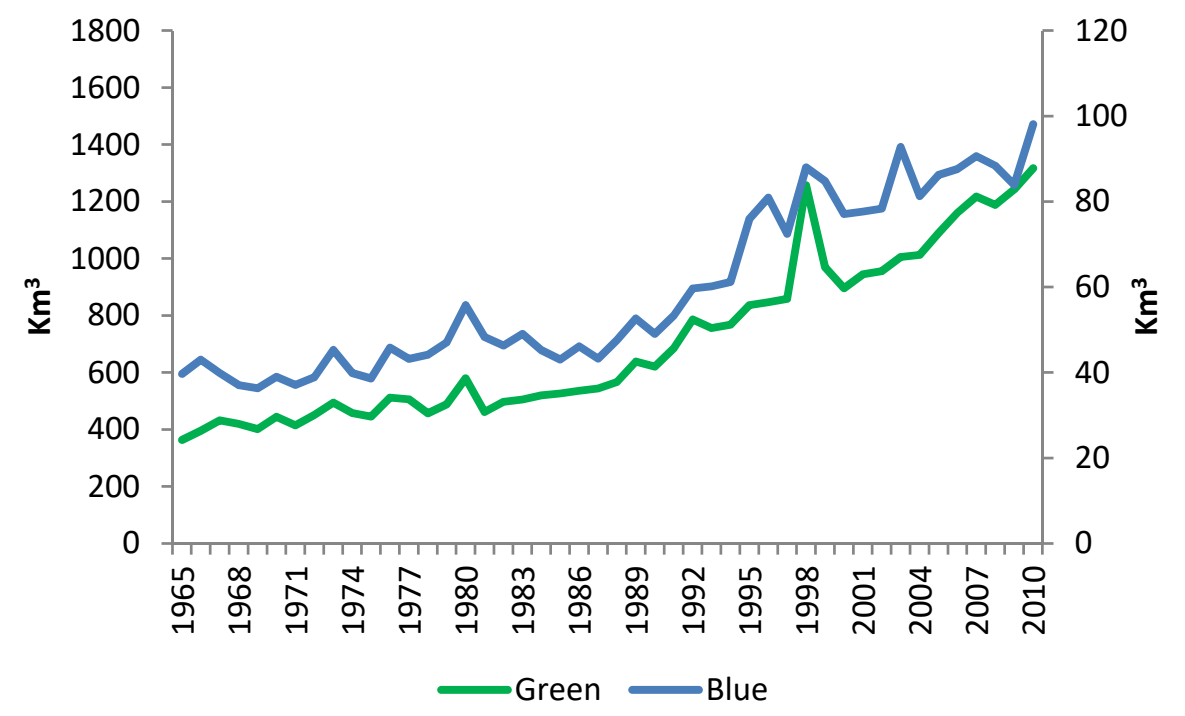

On the whole, the percentages shown in Table 1 of the share of the world regions of exports and imports, and the tendency followed by virtual water trade flows, are similar to those resulting when analyzing trade values, in monetary units (Serrano and Pinilla, 2011a).

As is observed in Table 1, the contribution of each of the regions of the world (Africa, North America, Asia and Pacific, Europe, the former Soviet Union, Latin America, and Oceania) to virtual water trade flows is not homogenous, with large differences in the shares of each area. The largest exporter of blue water was North America throughout the period, followed by Europe. The importance of the U.S. as an exporter of agri-food products, due to the development of a very high-productivity agriculture, an agrifood industry closely linked to it, and the huge expansion of the irrigated area during the $20^{\text {th }}$ century (Olmstead et al., 2000) explain the high virtual water exports of North America. Note that irrigated area in the USA went from 7.7 million acres in 1900 to 49.4 in 1992 (Carter et al., 2006).

The intense intra-European trade in agricultural and food products, clearly influenced by the processes of economic integration, together with the growing share of processed and high value-added agri-food exports, explains the importance and increasing weight of Europe in global virtual water trade (Serrano and Pinilla, 2011b). Although Table 1 and SI1 refer to interregional flows among the main regions in the world, all the exchanges of water through international trade are calculated in a disaggregated way, at the country and product level. In the case of green water, Latin America and North 
America appear as the most representative exporters, with shares of $26.6 \%$ and $25.2 \%$ respectively. The downward trend in the weight of Latin American was caused by its poor agricultural exports performance from the $1950 \mathrm{~s}$ until the last decade of the $20^{\text {th }}$ century (Serrano and Pinilla, forthcoming).

Table 1: Average contribution of world regions to virtual water exports and imports (\%)

\begin{tabular}{|c|c|c|c|c|c|c|c|c|c|c|}
\hline & $\begin{array}{c}1965- \\
1969\end{array}$ & $\begin{array}{c}1970- \\
1979\end{array}$ & $\begin{array}{c}1980- \\
1989\end{array}$ & $\begin{array}{c}1990- \\
1999\end{array}$ & $\begin{array}{l}2000- \\
2010\end{array}$ & $\begin{array}{c}1965- \\
1969\end{array}$ & $\begin{array}{c}1970- \\
1979\end{array}$ & $\begin{array}{c}1980- \\
1989\end{array}$ & $\begin{array}{c}1990- \\
1999\end{array}$ & $\begin{array}{l}2000- \\
2010\end{array}$ \\
\hline & \multicolumn{5}{|c|}{ Blue water exports } & \multicolumn{5}{|c|}{ Green water exports } \\
\hline Africa & 16.4 & 12.4 & 7.9 & 4.9 & 5.5 & 4.5 & 4.1 & 3.1 & 2.1 & 1.4 \\
\hline North America & 26.8 & 35.9 & 34.5 & 30.8 & 30.4 & 24.7 & 30.7 & 28.5 & 24.8 & 22.1 \\
\hline Asia and Pacific & 17.9 & 16.8 & 20.6 & 19.7 & 20.8 & 12.9 & 11.8 & 14.5 & 17.9 & 18.4 \\
\hline Europe & 15.9 & 18.8 & 22.5 & 22.1 & 22.6 & 17.2 & 17.4 & 20.8 & 20.1 & 18.9 \\
\hline Former Soviet Union & 0.5 & 0.3 & 0.2 & 6.0 & 3.4 & 2.0 & 0.7 & 0.2 & 5.8 & 6.3 \\
\hline Latin America & 17.7 & 11.6 & 8.4 & 9.5 & 10.9 & 30.7 & 26.3 & 24.6 & 24.5 & 28.3 \\
\hline Oceania & 4.8 & 4.2 & 5.8 & 7.1 & 6.4 & 7.9 & 9.0 & 8.4 & 4.7 & 4.5 \\
\hline \multirow[t]{2}{*}{ Total } & 100 & 100 & 100 & 100 & 100 & 100 & 100 & 100 & 100 & 100 \\
\hline & \multicolumn{5}{|c|}{ Blue water imports } & \multicolumn{5}{|c|}{ Green water imports } \\
\hline Africa & 3.0 & 6.1 & 8.5 & 5.3 & 6.4 & 3.4 & 4.8 & 6.4 & 5.2 & 6.4 \\
\hline North America & 12.2 & 9.2 & 7.8 & 8.5 & 9.5 & 16.1 & 13.3 & 10.9 & 9.0 & 8.8 \\
\hline Asia and Pacific & 26.4 & 33.4 & 34.6 & 32.9 & 33.1 & 21.9 & 26.7 & 29.5 & 26.7 & 32.6 \\
\hline Europe & 53.0 & 45.3 & 40.4 & 37.3 & 33.8 & 51.8 & 48.0 & 44.4 & 39.9 & 36.2 \\
\hline Former Soviet Union & 1.2 & 0.4 & 0.0 & 5.3 & 4.7 & 0.4 & 0.3 & 0.2 & 9.0 & 4.6 \\
\hline Latin America & 3.8 & 5.3 & 8.3 & 10.3 & 12.0 & 5.9 & 6.6 & 8.2 & 9.8 & 10.8 \\
\hline Oceania & 0.4 & 0.3 & 0.4 & 0.5 & 0.7 & 0.4 & 0.4 & 0.4 & 0.4 & 0.5 \\
\hline Total & 100 & 100 & 100 & 100 & 100 & 100 & 100 & 100 & 100 & 100 \\
\hline
\end{tabular}

Source: own elaboration using trade data from United Nations Statistics Division (UN, 2013) and water footprints from Mekonnen and Hoekstra $(2011,2012)$.

Looking at imports, Europe and Asia and Pacific were the largest importers of both blue and green virtual water during the period considered. Europe accounted for more than $50 \%$ of global water imports during the 1960 , but tended to decrease its importance, reaching a share of $36 \%$ today. This is related to the implementation of the Common Agricultural Policy that involved an increase in agricultural protectionism and a drop in the weight of European agricultural imports (Pinilla and Serrano, 2009). On the other hand, Asia and Pacific increased its significance in blue virtual water imports. The very strong economic growth in Asian countries since the 1980s, and especially in China, explain this rising importance in global virtual water imports. Table SI1 in the SI shows the average virtual water exports, imports, and balance of the regions in which we have divided the world, during each period. North America and Oceania were net exporters of water, Europe together with Asia and Pacific were net importers of both blue and green water, Latin America was a net exporter of blue water until 1989 (and stands out 
as the most remarkable net exporter of green water, particularly from 2000), and Africa appears as a net exporter of water until 1980, after which it became a net importer.

\subsection{Results at the country level and by products}

At the country level, interesting insights can be obtained from the analysis of countries with the highest global flows, and also the origins and destinations of those flows. Figures 2, 3 and SI1-SI4 in the SI show the largest net importers and exporters of green water and the five most important net exchanges of agricultural and food products for 1965, 1980, and 2010.

Figure SI2 shows that Latin American countries such as Brazil and Argentina exported most green water in 1965; Argentina exported wheat and maize to European countries such as the Netherlands and Italy, and Brazil used green water in the production of coffee, exported mainly to the USA. Developed countries that have traditionally been exporters of primary products, such as the USA, Canada and Australia, can also be seen as notable net exporters of green water. The USA exported large volumes of green water to the Netherlands and to Japan, the largest net importer of green water in the period. In this case, green water was embodied mainly in cereals like wheat and soya beans. Most of the green water from Canada or Australia was embodied in wheat.

The picture was somewhat different by 2010 (Figure SI4). The Americas (chiefly Brazil, Argentina, the USA, and Canada) continued to be the main exporter of green water in the world, and Italy, Japan and The Netherlands were the main destinations of virtual water flows. Nevertheless, China, with $14 \%$ of gross green virtual water imports in the world, is the largest net importer of green water today. Three of the five most important flows in the world go from the USA (raw cotton and soya beans), Brazil (wheat) and Argentina (soya beans) to China. Moreover, the exchange of water, mostly from the USA to Japan, is still significant (maize). (Further information on green water flows for the intermediate period, i.e., 1980, can be seen in the SI.)

As can be observed in Figures 2, 3 and SI1, for blue water, the USA appears as the highest net exporter in 1965, followed by Mexico and certain countries in the north of Africa, such as Algeria, Egypt, and Sudan. In contrast, Japan and France imported most blue 
water. As happened in the case of green water, the largest blue virtual water flow went from the USA to Japan, primarily in cereals and cotton. Important virtual blue water flows also took place as a result of the export of wine from Algeria to France, of cotton from Mexico to the USA and Japan, and cereals from the USA to the Netherlands.

Figure 2: Country net exports of blue water and top five net flows in the world, 1965. Source: own elaboration using trade data from United Nations Statistics Division (UN, 2013) and water footprints from Mekonnen and Hoekstra (2011, 2012).

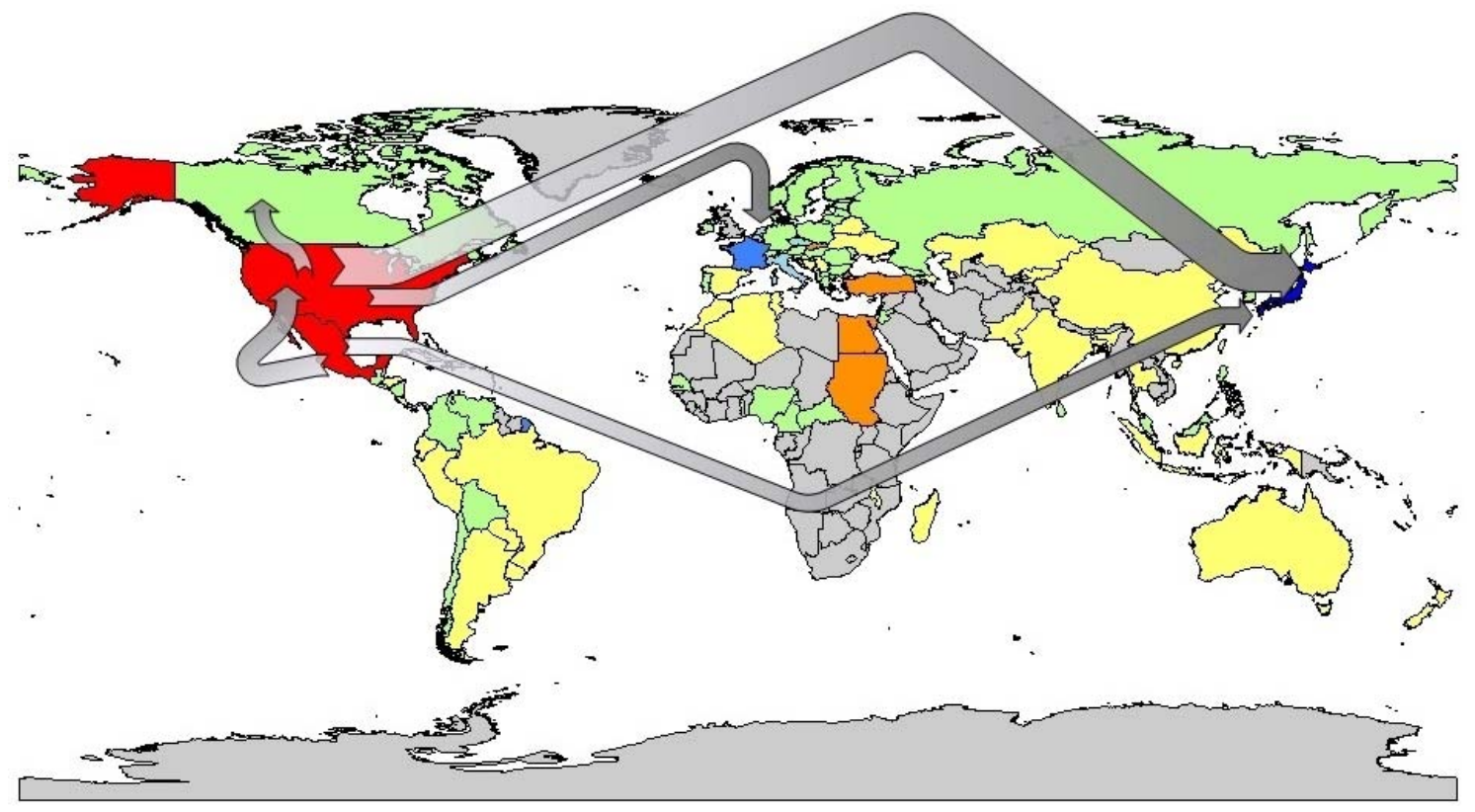

Thousand cubic meters

$-6100--5320$ 
Figure 3: Country net exports of blue water and top five net flows in the world, 2010. Source: own elaboration using trade data from United Nations Statistics Division (UN, 2013) and water footprints from Mekonnen and Hoekstra $(2011,2012)$.

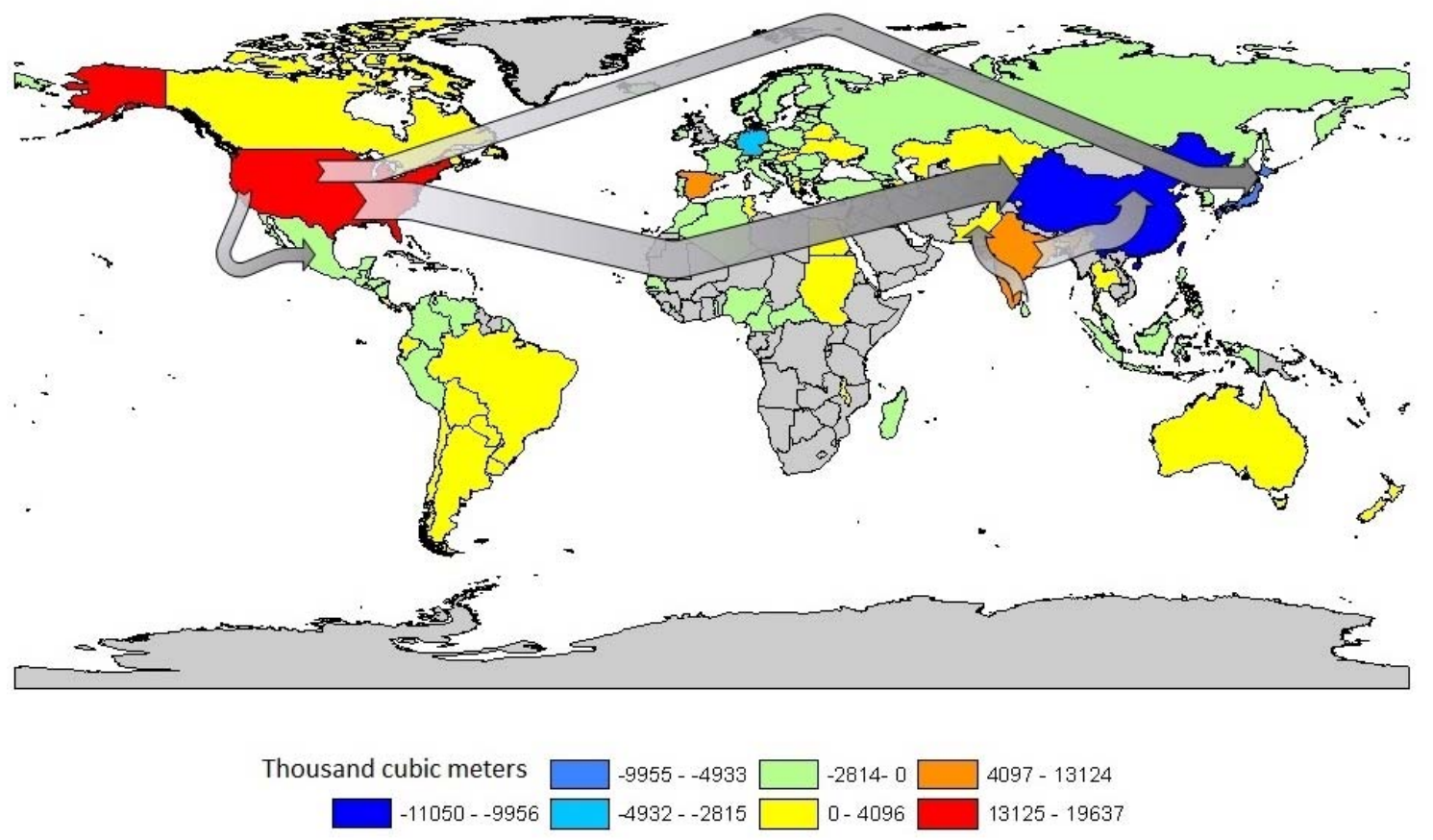

In 2010, the USA was still the largest blue virtual water exporter in the world, followed by India, Spain, Australia, and Argentina. China became the most significant importer of blue water in the world, with more than $14 \%$ of global blue water imports. Japan, Germany, Korea, and the United Kingdom were also notable net importers of blue water. While the USA blue water resources mainly went to China (soya beans), Japan (maize), and Mexico (cereals), Indian blue water was traded with China embodied in cotton and with Pakistan embodied in sugar.

One important feature to be analyzed is the relationship between water flows embodied in trade and the natural conditions (water endowments) of the countries. Following the proposal of Hoekstra and Hung (2005), Table 2 and Tables SI3, SI4 and SI5 display several water indicators (gross virtual imports and exports, net virtual water imports, scarcity, self-sufficiency, and dependency indexes) at the country level, calculated at the beginning and the end of the period studied (we use 2000 due to lack of data on water withdrawal at later periods for all the countries in the sample). Data for an intermediate year, 1980 are included in the SI Information. Population is included for reference. As in Hoekstra and Hung (2005), the scarcity index is obtained as the ratio between water availability and water withdrawal. The self-sufficiency index as defined by Hoekstra and 
Hung (2005), is the ratio between domestic water use (green and blue water withdrawn) and the sum of it and net virtual water imports. This index indicates the capacity of a country to meet its water demands with their own resources. On the contrary, the dependency index is calculated by dividing net virtual water imports by the sum of these imports and domestic water use. As we have previously said, for the calculation of the self-sufficiency and dependency indexes we consider virtual water imports and water withdrawal data. The former are estimated using information on the product water footprints; the latter reflect the water used or abstracted from surface or groundwater sources. Given the different nature of the data used for the calculations (water use and consumption), the results and conclusions derived from the self-sufficiency and dependency ratios must be interpreted with caution. As pointed out by Lutter and Giljum (2015), water abstraction and consumption exert different impacts on aquatic ecosystems. Whereas water use affects water flows in a concrete watershed, water consumption is related to ecosystems as a whole.

As can be seen, the United States, Brazil, Canada, India, Colombia, and China display the largest water availability in the world. The countries with the most abundant per capita water resources are Canada, New Zealand, and Latin American areas of Paraguay, Bolivia, Peru, and Venezuela. The countries with the lowest per capita measures are China, the USA, India, Indonesia, Pakistan, and Japan. From 1965 to 2000, water withdrawals tended to increase in almost all countries. The global population increased dramatically during these years, leading to decreased per capita water withdrawals in the majority of countries. Extracted water is used to meet domestic demands, but also to produce goods that have been exchanged through international trade.

According to the scarcity index, during these years scarcity grew in most countries in the world, with the most significant values in Egypt, Israel, Jordan, Pakistan, Tunisia, and Sudan. Some of these countries are important net exporters of water, in spite of being subject to a notable lack of water. As is shown in Table 2, most of the countries that were self-sufficient in 1965 showed a similar profile in 2010. The same happened for most countries dependent on foreign water resources. We find exceptions, such as Malaysia, Bolivia, France, Ireland, and Denmark that were very dependent on water from abroad in the 1960s that today appear as net exporters of water resources and are 
self-sufficient. According to our results, countries such as The Netherlands, Korea, Algeria, Israel, and Jordan have a high dependency index as a result of agricultural and food product imports. It is possible to find an increase in the self-sufficiency of Austria, Greece, Norway, Poland, and the United Kingdom. Finally, Senegal, Jordan, Peru, Venezuela, Israel, Nigeria, Morocco, Algeria, Mexico, and Japan notably increased their dependency on foreign water resources.

Table 2: Gross VWM, Gross VWX, Net VWM and sustainability indexes for 1965 and 2010

\begin{tabular}{|c|c|c|c|c|c|c|c|c|c|c|c|c|}
\hline \multirow[b]{2}{*}{ Country } & \multicolumn{6}{|c|}{1965} & \multicolumn{6}{|c|}{2010} \\
\hline & $\begin{array}{l}\text { Gross } \\
\text { VWM } \\
\left(\mathbf{k m}^{3}\right)\end{array}$ & $\begin{array}{l}\text { Gross } \\
\text { VWX } \\
\left(\mathbf{k m}^{3}\right)\end{array}$ & $\begin{array}{c}\text { Net } \\
\text { VWM } \\
\left(\mathbf{k m}^{3}\right)\end{array}$ & $\begin{array}{l}\text { Scar. } \\
\text { Index } \\
(\%)\end{array}$ & $\begin{array}{c}\text { SS } \\
\text { index } \\
(\%)\end{array}$ & $\begin{array}{c}\text { Dep. } \\
\text { index } \\
(\%)\end{array}$ & $\begin{array}{l}\text { Gross } \\
\text { VWM } \\
\left(\mathrm{km}^{3}\right)\end{array}$ & $\begin{array}{l}\text { Gross } \\
\text { VWX } \\
\left(\mathrm{km}^{3}\right)\end{array}$ & $\begin{array}{c}\text { Net } \\
\text { VWM } \\
\left(\mathrm{km}^{3}\right)\end{array}$ & $\begin{array}{c}\text { Scar. } \\
\text { Index } \\
(\%)\end{array}$ & $\begin{array}{c}\text { SS } \\
\text { index } \\
(\%)\end{array}$ & $\begin{array}{c}\text { Dep. } \\
\text { Index } \\
(\%)\end{array}$ \\
\hline Albania & 0.3 & 0 & 0.3 & 35 & 82 & 18 & 3.7 & 3.3 & 0.4 & 21 & 89 & 11 \\
\hline Algeria & 1.2 & 2.5 & -1.3 & 4 & 100 & 0 & 14.3 & 6.9 & 7.5 & 5 & 85 & 15 \\
\hline Argentina & 1.5 & 44.1 & -42.5 & 29 & 100 & 0 & 10.6 & 89.6 & -79 & 25 & 100 & 0 \\
\hline Australia & 1 & 19.4 & -18.4 & n.a. & 100 & 0 & 2.8 & 36.3 & -33.5 & 22 & 100 & 0 \\
\hline Austria & 1.6 & 0.6 & 1 & 23 & 76 & 24 & 0 & 0.1 & 0 & 2,181 & 100 & 0 \\
\hline Bolivia & 0.4 & 0.1 & 0.3 & 502 & 80 & 20 & 1.4 & 4.6 & -3.2 & 235 & 100 & 0 \\
\hline Brazil & 7.2 & 34.4 & -27.2 & 235 & 100 & 0 & 27.7 & 77 & -49.3 & 139 & 100 & 0 \\
\hline Bulgaria & 1 & 1.5 & -0.6 & 2 & 100 & 0 & 1.4 & 2.1 & -0.8 & 4 & 100 & 0 \\
\hline Cameroon & 0.1 & 1.4 & -1.3 & 714 & 100 & 0 & 0.4 & 3.9 & -3.4 & 295 & 100 & 0 \\
\hline Canada & 11.4 & 23.1 & -11.6 & 69 & 100 & 0 & 16.4 & 62.2 & -45.8 & n.a. & 100 & 0 \\
\hline Chile & 2.3 & 0.2 & 2.1 & 45 & 91 & 9 & 4.1 & 0 & 4 & 1 & 19 & 81 \\
\hline China & 9.2 & 8.2 & 1 & 6 & 100 & 0 & 24.8 & 9.2 & 15.6 & 9 & 50 & 50 \\
\hline Colombia & 1 & 8.5 & -7.6 & n.a. & 100 & 0 & 7.5 & 11.8 & -4.2 & 169 & 100 & 0 \\
\hline Denmark & 5.2 & 5 & 0.2 & 5 & 85 & 15 & 7 & 7.1 & -0.1 & 9 & 100 & 0 \\
\hline Ecuador & 0.2 & 1.8 & -1.5 & n.a. & 100 & 0 & 1.9 & 3.1 & -1.2 & 45 & 100 & 0 \\
\hline Egypt & 7.2 & 2.8 & 4.4 & 1 & 92 & 8 & 10.1 & 0.1 & 10 & 2 & 36 & 64 \\
\hline El Salvador & 0.7 & 1 & -0.2 & 35 & 100 & 0 & 2 & 2.2 & -0.2 & 18 & 100 & 0 \\
\hline Finland & 2.2 & 0.3 & 1.9 & 30 & 67 & 33 & 0.6 & 0 & 0.6 & 23 & 75 & 25 \\
\hline France & 24.9 & 7.7 & 17.2 & 7 & 64 & 36 & 31.9 & 33.5 & -1.6 & 7 & 100 & 0 \\
\hline Greece & 3.1 & 0.9 & 2.3 & 15 & 69 & 31 & 2.5 & 1.1 & 1.4 & 17 & 62 & 38 \\
\hline Guatemala & 0.4 & 2.5 & -2.1 & n.a. & 100 & 0 & 2.4 & 5.9 & -3.5 & 40 & 100 & 0 \\
\hline Hungary & 2.2 & 3 & -0.8 & 22 & 100 & 0 & 1.9 & 7.2 & -5.3 & 18 & 100 & 0 \\
\hline India & 1.3 & 12.6 & -11.3 & 4 & 100 & 0 & 26.3 & 29 & -2.7 & 3 & 100 & 0 \\
\hline Indonesia & 0.6 & 4.5 & -3.8 & 27 & 100 & 0 & 19.1 & 37.1 & -18 & 18 & 100 & 0 \\
\hline Ireland & 1.4 & 0.9 & 0.5 & 66 & 59 & 41 & 2.5 & 4.1 & -1.5 & n.a. & 100 & 0 \\
\hline Israel & 3.1 & 0.3 & 2.8 & 1 & 38 & 62 & 6.2 & 1.3 & 4.9 & 37 & 83 & 17 \\
\hline Italy & 37.9 & 2.2 & 35.7 & 5 & 54 & 46 & 60.6 & 26.7 & 33.9 & 10 & 21 & 79 \\
\hline Japan & 46 & 0 & 46.3 & 5 & 66 & 34 & 50 & 14.7 & 34.8 & 6 & 68 & 32 \\
\hline Jordan & 0.5 & 0 & 0.5 & 2 & 53 & 47 & 12.6 & 9.3 & 3.3 & 6 & 96 & 4 \\
\hline Madagascar & 0.3 & 2.4 & -2.1 & 21 & 100 & 0 & 0.5 & 1.4 & -1 & 20 & 100 & 0 \\
\hline Malawi & 0 & 0.5 & -0.5 & n.a. & 100 & 0 & 0 & 0.8 & -0.8 & 13 & 100 & 0 \\
\hline Malaysia & 3.8 & 1.2 & 2.6 & 57 & 79 & 21 & 14.3 & 29.4 & -15.1 & 62 & 100 & 0 \\
\hline Mexico & 1 & 14 & -13.4 & 8 & 100 & 0 & 31.5 & 1.3 & 30.2 & 3 & 46 & 54 \\
\hline Morocco & 1.9 & 1.9 & -0.1 & 3 & 100 & 0 & 9.7 & 3.1 & 6.6 & 8 & 56 & 44 \\
\hline Netherlands & 31.1 & 7.9 & 23.2 & 10 & 28 & 72 & 46.7 & 22.4 & 24.4 & 5 & 96 & 4 \\
\hline New Zealand & 1 & 7.9 & -6.8 & 273 & 100 & 0 & 1.1 & 15.3 & -14.1 & 69 & 100 & 0 \\
\hline Nicaragua & 0.2 & 2.7 & -2.5 & n.a. & 100 & 0 & 0.7 & 3.4 & -2.8 & 142 & 100 & 0 \\
\hline Nigeria & 0.4 & 0.2 & 0.2 & 79 & 94 & 6 & 6.8 & 0.7 & 6.1 & 1 & 23 & 77 \\
\hline Norway & 3 & 0.1 & 2.9 & 191 & 41 & 59 & 6.7 & 4.9 & 1.9 & 8 & 83 & 17 \\
\hline Pakistan & 0 & 0 & 0 & 2 & 100 & 0 & 5.4 & 2 & 3.5 & 99 & 85 & 15 \\
\hline Paraguay & 0.2 & 0.8 & -0.6 & 781 & 100 & 0 & 0.7 & 8.7 & -8 & 686 & 100 & 0 \\
\hline Peru & 3 & 2.1 & 0.9 & 101 & 95 & 5 & 6.5 & 3.6 & 2.9 & 5 & 82 & 18 \\
\hline Poland & 7.2 & 2.9 & 4.2 & 4 & 78 & 22 & 3.9 & 1.1 & 2.8 & 65 & 49 & 51 \\
\hline Portugal & 1.7 & 0.3 & 1.4 & n.a. & n.a. & n.a. & 6.6 & 1 & 5.6 & 136 & 62 & 38 \\
\hline Rep. of Korea & 2.8 & 0.1 & 2.7 & n.a. & n.a. & n.a. & 24.8 & 9.2 & 15.6 & 1 & 78 & 22 \\
\hline Romania & 0.4 & 2 & -1.5 & 11 & 100 & 0 & 2.8 & 3.2 & -0.4 & 23 & 100 & 0 \\
\hline Senegal & 0.9 & 2.3 & -1.4 & 29 & 100 & 0 & 2.1 & 0.8 & 1.3 & 48 & 64 & 36 \\
\hline Spain & 8.1 & 3 & 5.1 & 3 & 89 & 11 & 8.6 & 1.4 & 7.1 & 2 & 64 & 36 \\
\hline Sudan & 0.5 & 4.3 & -3.7 & 4 & 100 & 0 & 1.1 & 2.9 & -1.8 & 2 & 100 & 0 \\
\hline
\end{tabular}




\begin{tabular}{|c|c|c|c|c|c|c|c|c|c|c|c|c|}
\hline Sweden & 4.8 & 0.8 & 4 & 42 & 51 & 49 & 2.5 & 0.3 & 2.3 & 160 & 51 & 49 \\
\hline Thailand & 0.6 & 10.3 & -9.7 & n.a. & 100 & 0 & 10.4 & 25.6 & -15.2 & 8 & 100 & 0 \\
\hline Tunisia & 1 & 2.7 & -1.7 & 2 & 100 & 0 & 4.8 & 5.8 & -1 & 2 & 100 & 0 \\
\hline Turkey & 1.2 & 3.9 & -2.7 & 7 & 100 & 0 & 6.7 & 0 & 6.7 & 28 & 60 & 40 \\
\hline United Kingdom & 47.6 & 1.3 & 46.2 & 11 & 23 & 77 & 29 & 20.7 & 8.3 & 3 & 81 & 19 \\
\hline Uruguay & 0 & 2 & -1.8 & 214 & 100 & 0 & 3 & 4.9 & -1.6 & 38 & 100 & 0 \\
\hline USA & 53.9 & 92.5 & -38.6 & 6 & 100 & 0 & 77.2 & 187.6 & -110.4 & 6 & 100 & 0 \\
\hline Venezuela & 2.4 & 1.4 & 1 & 301 & 80 & 20 & 9.8 & 4.9 & 4.8 & 1 & 97 & 3 \\
\hline
\end{tabular}

VWM: green and blue virtual water imports, VWX: green and blue virtual water exports, Scar. Index: Scarcity index, SS index: Self-sufficiency index, Dep. Index: Dependency index. Source: own elaboration using trade data from United Nations Statistics Division (UN, 2013) and water footprints from Mekonnen and Hoekstra (2011, 2012).

In addition to the increased volume of virtual water traded, significant shifts in the agricultural and food products exchanged also took place (Table 3). An important group of goods, such as cereals, that entailed more than $32 \%$ of green virtual water trade during the 1970 s, experienced a notable loss of weight, declining to around $22 \%$ in the case of green water and $27 \%$ for blue water. Textile fibers also went through a reduction in their share, particularly in the case of blue water, from 33\% during the 1960 s to approximately $14 \%$ today, mainly due to the substitution of natural fibers by synthetic fibers. A similar decline occurred with the group coffee, tea and spices. Other crops and products made up for these reductions. This was the case of fruit and vegetables, which considerably increased their participation, primarily in blue water, accounting for $15 \%$ of total exchanges of blue water today. Dairy products and eggs ( $4 \%$ of blue water) as well as meat (6.9\% of blue water currently), also experienced an upturn, chiefly in blue water. Regarding green water, the meat group has remained quite stable at $11 \%$. Vegetable oils, staples of human diets, more than doubled their participation in commercial exchanges of green water. Eventually, crops commonly used as animal feed such as feed stuff or oil seeds, oil nuts, and kernels, show growing and outstanding percentages for green water, reaching $8 \%$ and $15.4 \%$ respectively. We have seen that the increasing level of development in certain regions of the world lead to an important change in world diets, with a growing weight of high value-added commodities, such as fruit, vegetables, dairy products, vegetable oils, and meat. The rise of meat and other goods derived from livestock resulted in an upward trend of animal feed crops and oil seeds. Changes in the product composition of virtual water trade tend to be similar when the composition of world trade in agri-food products is analyzed in monetary value. In this case, processed and high value-added commodities have also increased their share, whereas basic products have lost weight. Processed products of higher value 
have benefited from freer trade and from the new intra-industry trade patterns (Serrano and Pinilla, 2014).

Table 3: Average contribution of products to virtual water exports and imports (\%)

\begin{tabular}{lrrrrrrrrrr}
\hline & \multicolumn{4}{c}{ Blue water } & \multicolumn{5}{c}{ Green water } \\
\hline Sitc rev.1 product & $\mathbf{1 9 6 5 -}$ & $\mathbf{1 9 7 0 -}$ & $\mathbf{1 9 8 0}$ & $\mathbf{1 9 9 0 -}$ & $\mathbf{2 0 0 0}$ & $\mathbf{1 9 6 5 -}$ & $\mathbf{1 9 7 0 -}$ & $\mathbf{1 9 8 0 -}$ & $\mathbf{1 9 9 0 -}$ & $\mathbf{2 0 0 0 -}$ \\
classification & $\mathbf{1 9 6 9}$ & $\mathbf{1 9 7 9}$ & $\mathbf{1 9 8 9}$ & $\mathbf{1 9 9 9}$ & $\mathbf{2 0 1 0}$ & $\mathbf{1 9 6 9}$ & $\mathbf{1 9 7 9}$ & $\mathbf{1 9 8 9}$ & $\mathbf{1 9 9 9}$ & $\mathbf{2 0 1 0}$ \\
\hline \hline 00 Live animals & 1.1 & 0.9 & 0.8 & 0.6 & 0.5 & 3.6 & 2.6 & 2.2 & 1.3 & 1.0 \\
01 Meat and meat prep. & 5.3 & 5.6 & 5.5 & 5.9 & 6.9 & 13.2 & 11.3 & 11.6 & 10.0 & 11.1 \\
02 Dairy products and eggs & 2.7 & 3.2 & 3.4 & 3.7 & 4.1 & 3.2 & 3.6 & 4.0 & 3.9 & 4.0 \\
04 Cereals and cereal prep. & 26.2 & 31.5 & 29.7 & 28.8 & 26.9 & 34.5 & 33.8 & 27.0 & 26.5 & 22.1 \\
05 Fruit and vegetables & 6.9 & 7.9 & 9.2 & 12.9 & 15.0 & 2.6 & 3.5 & 4.2 & 4.9 & 5.6 \\
06 Sugar, sugar prep., honey & 5.2 & 5.9 & 5.2 & 6.5 & 5.5 & 2.1 & 2.3 & 2.0 & 2.2 & 2.2 \\
07 Coffee, tea, spices & 2.3 & 2.1 & 2.0 & 2.0 & 1.7 & 17.3 & 14.8 & 13.2 & 14.0 & 7.9 \\
08 Feed Stuff and unmilled cereals & 3.5 & 3.9 & 4.8 & 5.6 & 5.6 & 3.1 & 3.9 & 6.6 & 8.3 & 8.0 \\
09 Miscellaneous food prep. & 0.0 & 0.0 & 0.1 & 0.3 & 0.4 & 0.0 & 0.0 & 0.0 & 0.1 & 0.1 \\
11 Beverages & 3.2 & 1.5 & 0.9 & 1.5 & 1.5 & 0.5 & 0.7 & 0.8 & 0.9 & 0.9 \\
12 Tobacco & 0.4 & 0.4 & 0.3 & 0.4 & 0.4 & 0.6 & 0.4 & 0.3 & 0.3 & 0.3 \\
21 Hides, skins and furs & 0.4 & 0.4 & 0.8 & 1.6 & 0.7 & 0.9 & 1.0 & 1.8 & 1.7 & 1.2 \\
22 Oil seeds, oil nuts & 6.3 & 7.6 & 8.4 & 8.8 & 10.0 & 7.6 & 10.1 & 12.3 & 11.5 & 15.8 \\
26 Textile fibres, not manuf. & 32.7 & 22.7 & 20.6 & 15.1 & 13.9 & 5.5 & 4.1 & 3.1 & 2.3 & 2.2 \\
42 Fixed veg. oils and fats & 3.5 & 6.0 & 7.6 & 5.9 & 5.4 & 4.8 & 7.2 & 10.1 & 10.7 & 15.4 \\
59 Chemical materials & 0.1 & 0.1 & 0.1 & 0.1 & 0.2 & 0.2 & 0.1 & 0.2 & 0.2 & 0.3 \\
61 Leather, Ithr. manufs. & 0.1 & 0.2 & 0.4 & 0.6 & 1.3 & 0.3 & 0.5 & 0.8 & 1.2 & 1.7 \\
Total & 100 & 100 & 100 & 100 & 100 & 100 & 100 & 100 & 100 & 100 \\
\hline \hline
\end{tabular}

Source: own elaboration using trade data from United Nations Statistics Division (UN, 2013) and water footprints from Mekonnen and Hoekstra $(2011,2012)$.

\section{Discussion: Factors driving global virtual water flows in the long term}

In the following, we examine further the factors that could drive the increase in virtual water trade between 1965 and 2010. We apply a DA to study the role of growth in the volume of trade, changes in the main products traded, changes in the origin of virtual water, variations in the most important exporters and importers of water, and yield improvements.

Figure 4 shows the global impact that each of the factors previously defined had on the increase in blue and green water from 1965 to 2010. Scale effects, that is, the significant growth of commercial exchanges during these years, all other things constant, was responsible for most of the increase in blue and green water consumption. From 1965 to 2010, certain Latin-American countries, such as Mexico, and African countries such as Egypt, Algeria, and Sudan, reduced their share of the trade of embodied water resources. However, Asian regions, such as China, India, and Indonesia, along with Canada and Spain hugely increased their weights. These changes in the share of countries in the virtual water trade also involved a boost of exchanges of virtual water. 
Product compositional changes (variations in traded products), together with yield improvements at the global level, contributed to the slowdown in virtual water trade. In other words, without the key role of these two elements (composition and intensity effects) the virtual water trade would have increased by $1,328 \mathrm{~km}^{3}$ more. On the one hand, the decreasing shares of cereals, such as wheat and maize, highly intensive in green water, as well as the reduced importance of coffee, moderated green water consumption rise to a great extent. On the other hand, we observe an outstanding loss of weight of raw sugar and raw cotton, crops that embody large volumes of blue water and that consequently drove the leveling-off of blue virtual water flows. The fact that agricultural yields increased in most of the world involved a decrease in the volume of water necessary to produce a tonne of product, and therefore a deceleration of virtual water exchanges.

Figure 4: Factors explaining the increase in virtual water flows in the world, 1965-2010. Source: own elaboration using trade data from United Nations Statistics Division (UN, 2013) and water footprints from Mekonnen and Hoekstra (2011, 2012).

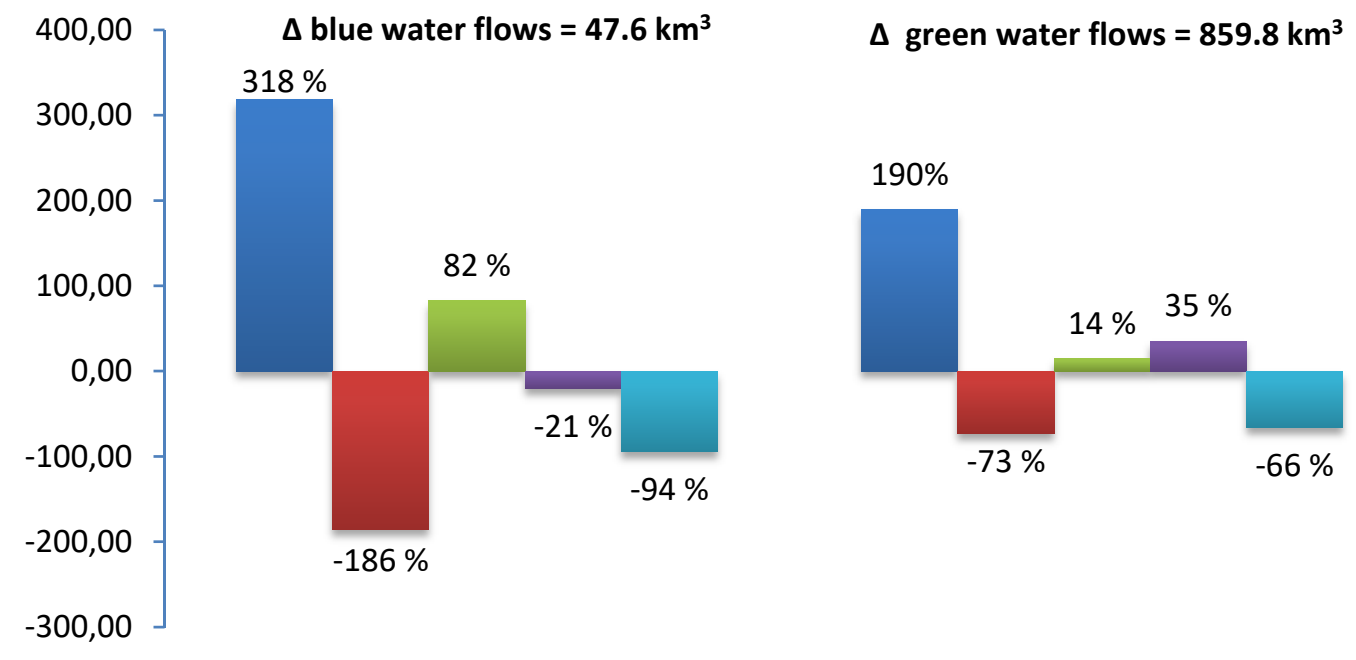

$\square$ scale effect $\square$ composition effect $\square$ trade share effect $\square$ localization effect $\square$ intensity effect

As is seen in Figure 4, localization had a negative effect on the blue virtual water trade, but a positive impact in the case of green water. As for blue water, on the whole, products were produced in less water-intensive countries and then exported, resulting in a smoother growth. Mexico and the USA were the most significant providers of blue water in the world, which appears to be constant over time. Although, in 1965, African countries such as Egypt and Algeria, and Oceania areas such as New Zealand and 
Australia, also stand out, they have since been superseded as exporters of virtual water by India and Spain, while the reallocation of the production of green-water-intensive goods have increased the virtual water trade. In this regard, green water had its origin mainly in the USA and Argentina during these years. Whereas Brazil, Australia, Colombia and the Philippines could be highlighted as important origins of green water trade flows in 1965, Canada, Indonesia, the Netherlands and India stand out today. These reallocations entailed greater pressures on global green water resources, as the production of agricultural goods tended to move to regions that are less efficient in the use of green water.

After examining the impact that these different effects exerted on the trend in global virtual water, we study their impact in seven regions (Table 4) of the world. (Results at the country level are given in Tables SI6 and SI7 in the SI.) Regarding exports, blue and green virtual water increased in all areas except Africa, where slight decreases took place, and a scale effect appears to be the most important factor driving blue and green water exports growth. However, there are certain regional disparities in the case of composition and trade share effects. As for green water, compositional changes partially offset the increase in virtual water flows, displaying a higher contribution in Latin America and North America. In the case of blue water, the former effect had an important contribution to the moderation of the virtual water trade in Latin America, but triggered the exchanges of virtual water in Oceania and in the Former Soviet Union. Changes in the importance of countries in exports, i.e. the trade share effect, involved the stabilization of virtual water trade in North America, Latin America, Oceania and Africa. However, it boosted the exchanges of virtual water in Europe and the Former Soviet Union. For Asia, the trade share effect leads blue virtual water exports to level off but entails a slight growth of green water exports. Finally, yield improvements occurred in every region of the world and mitigated larger increases in the virtual water trade. As an example, these advances reduced virtual water flows in Asia and Europe by approximately $204 \mathrm{~km}^{3}$.

Table 4: Change in virtual water flows and decomposition analysis effects, 1965-2010

\begin{tabular}{cccccccccccc}
\hline \hline VWX & SE & CE & TE & IE & VWM & SE & CE & LE & TE & IE \\
Change $\left(\mathrm{km}^{3}\right)$ & $(\%)$ & $(\%)$ & $(\%)$ & $(\%)$ & Change $\left(\mathrm{km}^{3}\right)$ & $(\%)$ & $(\%)$ & $(\%)$ & $(\%)$ & $(\%)$ \\
\hline \hline
\end{tabular}




\begin{tabular}{|c|c|c|c|c|c|c|c|c|c|c|c|}
\hline \multicolumn{12}{|c|}{ Blue water } \\
\hline Africa & -3.1 & -631 & 109 & 572 & 51 & 5.4 & 122 & -26 & 59 & -6 & -49 \\
\hline North America & 16.7 & 241 & -25 & -59 & -57 & 3.4 & 480 & -99 & -159 & -38 & -83 \\
\hline Asia & 10.4 & 274 & 11 & -63 & -122 & 19.1 & 225 & -162 & 124 & -6 & -80 \\
\hline Europe & 15.4 & 163 & -11 & 29 & -81 & 8.2 & 890 & -378 & -107 & -71 & -234 \\
\hline Fmr. Soviet Union & 3.6 & 54 & 13 & 58 & -25 & 2.6 & 127 & -833 & 854 & 0 & -48 \\
\hline Latin America & 3.7 & 630 & -344 & -74 & -113 & 8.4 & 101 & 1 & 51 & -14 & -40 \\
\hline Oceania & 2.2 & 362 & 14 & -184 & -92 & 0.6 & 162 & -39 & 28 & -6 & -45 \\
\hline \multicolumn{12}{|c|}{ Green water } \\
\hline Africa & -6.2 & -889 & 16 & 913 & 60 & 70.5 & 120 & -50 & 66 & 12 & -49 \\
\hline North America & 144.6 & 274 & -50 & -54 & -71 & 35.3 & 572 & -180 & -204 & 19 & -107 \\
\hline Asia & 184.4 & 142 & -6 & 9 & -45 & 353.6 & 127 & -84 & 52 & 47 & -42 \\
\hline Europe & 183.5 & 142 & -6 & 69 & -104 & 235.8 & 314 & -70 & -54 & 34 & -123 \\
\hline Fmr Soviet Union & 101.2 & 62 & -17 & 90 & -35 & 58.4 & 51 & -79 & 97 & 59 & -27 \\
\hline Latin America & 221.4 & 207 & -55 & 2 & -54 & 100.4 & 115 & -17 & 35 & 6 & -39 \\
\hline Oceania & 30.5 & 346 & -7 & -175 & -63 & 5.9 & 134 & -30 & 18 & 16 & -38 \\
\hline
\end{tabular}

VWX change: change in virtual water exports $\left(\mathrm{km}^{3}\right)$, VWM change: change in virtual water imports $\left(\mathrm{km}^{3}\right)$, SE: Scale effect (\%), CE: Composition effect (\%), LE: localization effect (\%), TE: Trade share effect (\%), IE: Intensity effect (\%)

Source: own elaboration using trade data from United Nations Statistics Division (UN, 2013) and water footprints from Mekonnen and Hoekstra $(2011,2012)$.

When we look at the explanatory factors of the increase in virtual water imports at the regional level, again the scale effect is the main contributing factor to their growth. Product compositional changes drove virtual water stabilization, with the exception of green water in Latin America, where it showed a small but positive sign. Changes in the origin of products led to a moderation of the embodied blue and green water in imports in Europe and Latin America. As happened with exports, yield improvements boosted the deceleration of the virtual water exchanges all over the world, particularly in Europe and North America. Whereas variations in the share of countries in international trade led to a reduction of blue water, the trade share effect had the opposite impact for green water, triggering its exchange. This means that the growing presence of certain countries in international trade involved an increase in the exchanges of blue water because they demanded products that embody a high volume of blue water, while the greater share of these areas in international trade led to a slowing of green virtual water trade flows.

The analysis of the determinants of virtual water trade flows points to the increasing separation of consumer and producer responsibilities regarding water resources, meaning that consumption of products from other parts of the world necessarily entails the use of water from distant places. In some cases, the intensity of commercial exchange generates large pressures on water resources. An illustrative example of this issue is the food industry in Spain, one of the major global exporters of food. The 
significant increase in Spain's net exports explains over $60 \%$ of the growth of blue water consumption in Spain between 1960 and 2010 (Duarte et al., 2015a). Hence, the concentration of a growing part of agricultural production in one of the most arid regions in the world poses pressing problems for the sustainability of these activities (Cazcarro et al., 2015).

\section{Conclusions}

This paper has studied global virtual water trade flows from 1965 to 2010 . To the best of our knowledge, this is one of the first attempts to estimate the exchanges of water embodied in agricultural and food products over the long term, explaining the global and country trends of virtual water, following an economic and historical interpretation. We examine in depth the impact of economic change on virtual water distribution over many years, focusing on the effects of economic integration, globalization, and the growth of international trade on water.

We show that the commercial integration between 1965 and 2010, the period of the second wave of globalization, entailed large pressures on water resources at the global level, supporting the findings of the literature on this topic (Clark et al., 2015). The changes in the composition of trade as a result of the decline of the exchanges of waterintensive crops such as cotton, coffee, maize, and rice alleviated pressures on water. The same phenomenon happened with yield improvements, which also contributed to alleviate the pressure on water resources.

As we have seen, the linkages and dependencies among countries tended to strengthen during this period. In order to set a general pattern, it is necessary to consider natural and economic variables that may condition the volume and trajectory of virtual water trade flows. On the whole, the availability of such natural resources as water and land, together with the level of economic development, can contribute to our understanding. Hence, developed countries with less land per capita usually show a high dependence on foreign water. This is the case of European countries like the United Kingdom, Italy, the Netherlands, and Portugal, and certain other countries, such as Israel, Japan, and Korea behave in the same way. Similarly, developing countries that need to import large volumes of agricultural and food products are also dependent on foreign water, as for 
instance, China, Egypt, and Mexico. For countries with high net exports of virtual water, we find different patterns; there are the developed countries that are abundant in land and that have historically been exporters of agricultural products, such as the USA, Canada, Australia, and New Zealand, and then there are the emerging countries, also abundant in land, with a long-term specialization in agricultural exports, such as Argentina, Brazil, Indonesia, Thailand, and Malaysia. These patterns have hardly changed throughout this period. Some industrialized countries, with relatively limited availability of land tend to externalize the most intensive production systems to emerging regions that stand out for being mostly producers of primary inputs and agricultural goods, as well as to industrialized countries abundant in land.

Our main findings suggest the need to analyze environmental problems at the global level, since the growing integration in international trade of many countries is essential to an understanding of their final water consumption (Hoekstra and Chapagain, 2008). Even for the case of water resources that show a local dimension and are commonly managed at the basin level, globalization is of global concern, and there is a growing pressure in certain areas of the world. Together with water-abundant countries, we can also find other regions that, given their economic competitiveness in certain products, and thanks to their climatic conditions, or the construction of hydraulic infrastructures, tend to specialize in - and export - goods intensive in blue water. This involves important pressures on blue water resources. Increasing globalization involves diverse consequences from an environmental perspective, which require a more efficient use of natural resources in, for example, a country abundant in natural capital that exports to other countries where that resource is scarce. It is a fact that globalization can generate or exacerbate environmental problems. Good commercial opportunities can induce economic specializations that involve more pressures on natural resources. Under these circumstances, the economic logic, i.e. the profitability of the exporting specialization, comes into conflict with the environmental logic and the maintenance of water ecosystems (see Cazcarro et al. (2015) for an example of this conflict for the case of Spain). Our results suggest the existence of room for improvement, both at the local and global levels, to alleviate the impacts on water resources. First, the work of improving the technological conditions at the local level is a determining factor for water pressure 
alleviation. In this regard, significant improvements in water productivity can be achieved by reducing water losses, in the field and in the system (D. Chukalla et al., 2015). In this same line, the reduction of technological gaps between and within countries can be an important factor for improving water productivity of rain-fed products, and for the alleviation of water pressures in certain regions of the world. Second, the water footprint is a consumption-based indicator (Hoekstra and Chapagain, 2008). Thus, behind the evolution of trade and the water embodied in agricultural flows, we must highlight the role of the consumer at the end of the supply chain, as a driver of economic activity and trade and, in consequence, as one who shares the responsibility for environmental pressures. Increased environmental awareness of consumers, and the path towards more sustainable lifestyles, can have a measurable effect on global water pressures. In this context, measures such as product labelling and communication strategies that show responsibility and the effects of lifestyles can be considered at different decisional levels. Finally, our results suggest the existence of a strong link between global and national economic trends and the environmental impacts that, as in the case of water, may have a local character. The inclusion of water foot-printing assessment agendas as a measure of economic relationships, and their impact on resources, and of the internal and external impact of the production and trade of countries, can inform policy actions, at every level, for the definition of sustainable development strategies.

Accordingly, in the light of historical processes, it seems necessary to look globally for a better understanding of the link between economic growth, international trade, and environmental pressures. To that end, it is essential to develop useful tools to accurately measure impacts on water resources throughout the global chains of production, distribution and consumption.

\section{Acknowledgements}

This work has been partially supported by a grant, reference AP2009-3135, from the Government of Spain and by the Ministry of Science and Innovation of the Spanish Government, projects ECO2012-3328 and ECO2013-41353-P, and the Department of 
Science, Technology and Universities of the Government of Aragon (Research Groups 'Agrifood Economic History' and "Growth, Demand and Natural Resources").

\section{References}

Allan, T., 1997. Virtual water: a long term solution for water short Middle Eastern economies, 1997 British Association Festival of Science, Water and Development Session Roger Stevens Lecture Theatre, University of Leeds.

Allen, R.G., Pereira, L.S., Raes, D., Smith, M., 1998. Crop evapotranspiration. Guidelines for computing crop water requirements. FAO Irrigation and drainage paper 56.

Bocchiola, D., Nana, E., Soncini, A., 2013. Impact of climate change scenarios on crop yield and water footprint of maize in the Po valley of Italy. Agricultural Water Management 116, 50-61.

Carter, S.B., Gartner, S.S., Haines, Michael R. , Olmstead, A.L., Sutch, R., Wright, G., 2006. The Historical Statistics of the United States Millennium Edition, Millennium edition ed. Cambridge University Press.

Cazcarro, I., Duarte, R., Martín-Retortillo, M., Pinilla, V., Serrano, A., 2015. How Sustainable is the Increase in the Water Footprint of the Spanish Agricultural Sector? A Provincial Analysis between 1955 and 2005-2010. Sustainability 7, 5094-5119.

Cazcarro, I., Duarte, R., Sánchez-Chóliz, J., 2013. Economic growth and the evolution of water consumption in Spain: A structural decomposition analysis. Ecological Economics 96, 51-61.

Clark, S., Sarlin, P., Sharma, A., Sisson, S.A., 2015. Increasing dependence on foreign water resources? An assessment of trends in global virtual water flows using a self-organizing time map. Ecological Informatics 26, Part 2, 192-202.

Chenoweth, J., Hadjikakou, M., Zoumides, C., 2014. Quantifying the human impact on water resources: a critical review of the water footprint concept. Hydrol. Earth Syst. Sci. 18, 2325-2342.

D. Chukalla, A., S. Krol, M., Y. Hoekstra, A., 2015. Green and blue water footprint reduction in irrigated agriculture: effect of irrigation techniques, irrigation strategies and mulching. Hydrol. Earth Syst. Sci. Discuss. 12, 6945-6979.

Dalin, C., Konar, M., Hanasaki, N., Rinaldo, A., Rodriguez-Iturbe, I., 2012. Evolution of the global virtual water trade network. Proceedings of the National Academy of Sciences.

Deng, G., Wang, L., Song, Y., 2015. Effect of Variation of Water-Use Efficiency on Structure of Virtual Water Trade - Analysis Based on Input-Output Model. Water Resources Management 29, 2947-2965.

Dietzenbacher, E., Los, B., 1998. Structural Decomposition Techniques: Sense and Sensitivity. Economic Systems Research 10, 307-324. 
Doorenbos, J., Kassam, A.H., 1986. Yield response to water. . FAO, Rome.

Duarte, R., Pinilla, V., Serrano, A., 2014a. The effect of globalisation on water consumption: A case study of the Spanish virtual water trade, 1849-1935. Ecological Economics 100, 96-105.

Duarte, R., Pinilla, V., Serrano, A., 2014b. Looking backward to look forward: water use and economic growth from a long-term perspective. Applied Economics 46, 212-224.

Duarte, R., Pinilla, V., Serrano, A., 2014c. The water footprint of the Spanish agricultural sector: 1860-2010. Ecological Economics 108, 200-207.

Duarte, R., Pinilla, V., Serrano, A., 2015a. Globalization and natural resources: the expansion of the Spanish agrifood trade and its impact on water consumption, 1965-2010. Regional Environmental Change.

Duarte, R., Pinilla, V., Serrano, A., 2015b. The Spanish food industry on global supply chains and its impact on water resources. Water (Switzerland) 7, 132-152.

FAO, 2013. FAOSTAT Database on Agriculture. Food and Agriculture Organization of the United Nations, Rome, Italy.

FAO, 2014. AQUASTAT database.

Federico, G., 2005. Feeding the world: an economic history of agriculture, 1800-2000. Princeton University Press, Princeton.

Feng, K., Chapagain, A., Suh, S., Pfister, S., Hubacek, K., 2011. COMPARISON OF BOTTOM-UP AND TOP-DOWN APPROACHES TO CALCULATING THE WATER FOOTPRINTS OF NATIONS. Economic Systems Research 23, 371-385.

Feng, K., Siu, Y.L., Guan, D., Hubacek, K., 2012. Assessing regional virtual water flows and water footprints in the Yellow River Basin, China: A consumption based approach. Applied Geography $32,691-701$.

Guieysse, B., Béchet, Q., Shilton, A., 2013. Variability and uncertainty in water demand and water footprint assessments of fresh algae cultivation based on case studies from five climatic regions. Bioresource Technology 128, 317-323.

Haberl, H., Erb, K.-H., Krausmann, F., 2001. How to calculate and interpret ecological footprints for long periods of time: the case of Austria 1926-1995. Ecological Economics 38, 25-45.

Hoekstra, A.Y., Chapagain, A.K., 2008. Globalization of water: Sharing the planet's freshwater resources. Blackwell Publishing, Oxford, UK.

Hoekstra, A.Y., Chapagain, A.K., Aldaya, M.M., Mekonnen, M.M., 2011. The water footprint assessment manual: Setting the global standard. Earthscan, London, UK.

Hoekstra, A.Y., Hung, P.Q., 2005. Globalisation of water resources: international virtual water flows in relation to crop trade. Global Environmental Change 15, 45-56. 
Hoekstra, A.Y., Mekonnen, M.M., 2012. The water footprint of humanity. Proceedings of the National Academy of Sciences 109, 3232-3237.

Hoekstra, R., van den Bergh, J.J.M., 2002. Structural Decomposition Analysis of Physical Flows in the Economy. Environmental and Resource Economics 23, 357-378.

Konar, M., Hussein, Z., Hanasaki, N., Mauzerall, D.L., Rodriguez-Iturbe, I., 2013. Virtual water trade flows and savings under climate change. Hydrol. Earth Syst. Sci. Discuss. 10, 67-101.

Kondo, K., 2005. Economic analysis of water resources in Japan: using factor decomposition analysis based on input-output tables. Environmental Economics and Policy Studies 7, 109-129. Lenzen, M., Wiedmann, T., Barney, F., Dey, C., Widmer-Cooper, A., Williams M, R., O., 2001. Forecasting the Ecological Footprint of Nations: a blueprint for a dynamic approach. ISA Research Paper 07/01.

Lutter, S., Giljum, S., 2015. Developing targets for global resource use, targets for freshwater use. IntRESS Working Paper 2.4, Vienna University of Economics and Business.

Mekonnen, M.M., Hoekstra, A.Y., 2011. The green, blue and grey water footprint of crops and derived crop products. Hydrol. Earth Syst. Sci. 15, 1577-1600.

Mekonnen, M.M., Hoekstra, A.Y., 2012. A Global Assessment of the Water Footprint of Farm Animal Products. Ecosystems 15, 401-415.

Olmstead, A.L., Rhode, P.W., Olmstead, A.L., Rhode., P.W., 2000. The Transformation of Northern Agriculture, 1910-1990. The Cambridge Economic History of the United States. Cambridge University Press.

Pinilla, V., Serrano, R., 2009. Agricultural and Food Trade in the European Union since 1963, in: Patel, K. (Ed.), Fertile Ground por Europe? The History of European Integration and the Common Agricultural Policy since 1945. Nomos Publishers Baden-Baden, pp. 273-300.

Rask, K.J., Rask, N., 2011. Economic development and food production-consumption balance: A growing global challenge. Food Policy 36, 186-196.

Renault, D., 2002. Value of virtual water in food: principles and virtues, in: Hoekstra, A.Y. (Ed.), Virtual water trade: proceedings of the international expert meeting on virtual water trade. UNESCO-IHE, Delft.

Rockström, J., 2003. Water for food and nature in drought-prone tropics: Vapour shift in rainfed agriculture. Philosophical Transactions of the Royal Society B: Biological Sciences 358, 19972009.

Rockström, J., Lannerstad, M., Falkenmark, M., 2007. Assessing the water challenge of a new green revolution in developing countries. Proceedings of the National Academy of Sciences of the United States of America 104, 6253-6260. 
Schmitz, C., Biewald, A., Lotze-Campen, H., Popp, A., Dietrich, J.P., Bodirsky, B., Krause, M., Weindl, I., 2012. Trading more food: Implications for land use, greenhouse gas emissions, and the food system. Global Environmental Change 22, 189-209.

Schmitz, C., Lotze-Campen, H., Gerten, D., Dietrich, J.P., Bodirsky, B., Biewald, A., Popp, A., 2013. Blue water scarcity and the economic impacts of future agricultural trade and demand. Water Resources Research 49, 3601-3617.

Serrano, R., Pinilla, V., 2010. Causes of world trade growth in agricultural and food products, 1951-2000: a demand function approach. Applied Economics 42, 3503-3518.

Serrano, R., Pinilla, V., 2011a. The Evolution and Changing Geographical Structure of World Agrifood Trade, 1950-2000. Revista de Historia Industrial, 95-123.

Serrano, R., Pinilla, V., 2011b. Agricultural and Food Trade in European Union Countries, $1963-$ 2000: A Gravity Equation Approach. Economies et Sociétés (Serie'Histoire Economique Quantitative'), 191-229.

Serrano, R., Pinilla, V., 2014. Changes in the structure of world trade in the agri-food industry: the impact of the home market effect and regional liberalization from a long-term perspective, 1963-2010". Agribusiness: an International Journal 30, 165-183.

Serrano, R., Pinilla, V., Forthcoming. The Declining Role of Latin America in Global Agricultural Trade, 1963-2000. Journal of Latin American Studies.

Shi, J., Liu, J., Pinter, L., 2014. Recent evolution of China's virtual water trade: analysis of selected crops and considerations for policy. Hydrol Earth Syst Sci 18, 1349-1357.

Siebert, S., Döll, P., 2010. Quantifying blue and green virtual water contents in global crop production as well as potential production losses without irrigation. Journal of Hydrology 384, 198-217.

Steen-Olsen, K., Weinzettel, J., Cranston, G., Ercin, A.E., Hertwich, E.G., 2012. Carbon, Land, and Water Footprint Accounts for the European Union: Consumption, Production, and Displacements through International Trade. Environmental Science \& Technology 46, 1088310891.

Tamea, S., Carr, J.A., Laio, F., Ridolfi, L., 2014. Drivers of the virtual water trade. Water Resources Research 50, 17-28.

UN, 2013. Comtrade. United Nations, New York.

Vanham, D., Mekonnen, M.M., Hoekstra, A.Y., 2013. The water footprint of the EU for different diets. Ecological Indicators 32, 1-8.

WorldBank, 2014. World Development Indicators Online (WDI) database.

Yang, H., Wang, L., Zehnder, A.J.B., 2007. Water scarcity and food trade in the Southern and Eastern Mediterranean countries. Food Policy 32, 585-605. 
Yu, Y., Hubacek, K., Feng, K., Guan, D., 2010. Assessing regional and global water footprints for the UK. Ecological Economics 69, 1140-1147.

Zhan-Ming, C., Chen, G.Q., 2013. Virtual water accounting for the globalized world economy: National water footprint and international virtual water trade. Ecological Indicators 28, 142-149.

Zhuo, L., Mekonnen, M.M., Hoekstra, A.Y., 2014. Sensitivity and uncertainty in crop water footprint accounting: a case study for the Yellow River basin. Hydrol. Earth Syst. Sci. 18, 22192234. 


\section{Supplementary Information}

Table SI1: Average virtual water exports, imports and balance $\left(\mathrm{km}^{3}\right)$

\begin{tabular}{|c|c|c|c|c|c|c|c|c|c|c|}
\hline & $\begin{array}{c}1965- \\
1969 \\
\end{array}$ & $\begin{array}{c}1970- \\
1979 \\
\end{array}$ & $\begin{array}{c}1980- \\
1989 \\
\end{array}$ & $\begin{array}{c}1990- \\
1999 \\
\end{array}$ & $\begin{array}{l}2000- \\
2010 \\
\end{array}$ & $\begin{array}{c}1965- \\
1969 \\
\end{array}$ & $\begin{array}{c}1970- \\
1979 \\
\end{array}$ & $\begin{array}{c}1980- \\
1989 \\
\end{array}$ & $\begin{array}{c}1990- \\
1999 \\
\end{array}$ & $\begin{array}{l}2000- \\
2010 \\
\end{array}$ \\
\hline & \multicolumn{5}{|c|}{ Blue water exports } & \multicolumn{5}{|c|}{ Green water exports } \\
\hline Africa & 5.3 & 4.5 & 3.5 & 3.1 & 4.8 & 15.7 & 15.9 & 14.5 & 16.2 & 13.5 \\
\hline North America & 7.2 & 11.1 & 13.5 & 19.6 & 27.3 & 67.3 & 107.3 & 123.9 & 194.3 & 249.4 \\
\hline Asia and Pacific & 4.3 & 4.9 & 7.7 & 12.2 & 19.7 & 36.1 & 41.1 & 63.8 & 142.8 & 213.9 \\
\hline Europe & 3.8 & 5.6 & 8.6 & 13.9 & 19.6 & 40.3 & 57.9 & 88.8 & 153.7 & 209.7 \\
\hline Former Soviet Union & 0.1 & 0.1 & 0.1 & 3.8 & 3.2 & 5.7 & 3.0 & 1.0 & 45.3 & 76.0 \\
\hline Latin America & 5.0 & 4.1 & 3.4 & 5.8 & 10.0 & 77.3 & 88.0 & 106.1 & 183.2 & 334.8 \\
\hline Oceania & 1.4 & 1.4 & 2.3 & 4.4 & 5.9 & 21.2 & 31.4 & 35.3 & 36.7 & 49.0 \\
\hline \multirow[t]{2}{*}{ Total } & 27.1 & 31.6 & 39.1 & 62.8 & 90.5 & 263.6 & 344.7 & 433.5 & 772.2 & $1,146.3$ \\
\hline & \multicolumn{5}{|c|}{ Blue water imports } & \multicolumn{5}{|c|}{ Green water imports } \\
\hline Africa & 0.8 & 1.9 & 3.3 & 3.3 & 5.9 & 8.7 & 15.4 & 26.7 & 40.8 & 74.9 \\
\hline North America & 3.5 & 3.1 & 3.2 & 5.3 & 8.3 & 45.4 & 48.3 & 48.9 & 70.4 & 98.6 \\
\hline Asia and Pacific & 6.9 & 10.4 & 13.5 & 20.7 & 30.9 & 59.3 & 92.4 & 127.4 & 206.9 & 376.8 \\
\hline Europe & 14.4 & 14.4 & 15.8 & 23.3 & 29.8 & 133.4 & 163.9 & 191.4 & 302.6 & 413.1 \\
\hline Former Soviet Union & 0.2 & 0.1 & 0.0 & 3.3 & 4.2 & 0.9 & 0.7 & 1.1 & 71.0 & 53.9 \\
\hline Latin America & 1.0 & 1.7 & 3.3 & 6.6 & 10.8 & 14.9 & 22.6 & 36.1 & 77.4 & 122.9 \\
\hline Oceania & 0.1 & 0.1 & 0.1 & 0.3 & 0.6 & 1.0 & 1.3 & 2.0 & 3.1 & 6.1 \\
\hline \multirow[t]{2}{*}{ Total } & 27.1 & 31.6 & 39.1 & 62.8 & 90.5 & 263.6 & 344.7 & 433.5 & 772.2 & $1,146.3$ \\
\hline & \multicolumn{5}{|c|}{ Blue balance } & \multicolumn{5}{|c|}{ Green balance } \\
\hline Africa & 4.5 & 2.7 & 0.3 & -0.1 & -1.0 & 7.1 & 0.5 & -12.2 & -24.6 & -61.4 \\
\hline North America & 3.6 & 8.0 & 10.3 & 14.3 & 19.0 & 21.9 & 59.1 & 75.0 & 123.9 & 150.8 \\
\hline Asia and Pacific & -2.7 & -5.5 & -5.8 & -8.5 & -11.2 & -23.2 & -51.3 & -63.6 & -64.2 & -163.0 \\
\hline Europe & -10.6 & -8.9 & -7.1 & -9.4 & -10.2 & -93.2 & -106.1 & -102.6 & -148.9 & -203.4 \\
\hline Former Soviet Union & -0.1 & 0.0 & 0.1 & 0.4 & -1.0 & 4.8 & 2.3 & 0.0 & -25.6 & 22.1 \\
\hline Latin America & 4.0 & 2.4 & 0.1 & -0.7 & -0.8 & 62.4 & 65.4 & 70.0 & 105.8 & 211.9 \\
\hline Oceania & 1.3 & 1.3 & 2.1 & 4.1 & 5.2 & 20.2 & 30.1 & 33.4 & 33.6 & 43.0 \\
\hline Total & 0.0 & 0.0 & 0.0 & 0.0 & 0.0 & 0.0 & 0.0 & 0.0 & 0.0 & 0.0 \\
\hline
\end{tabular}

Source: own elaboration using trade data from United Nations Statistics Division (UN, 2013) and water footprints from Mekonnen and Hoekstra $(2011,2012)$. 
Table SI2: Similarity index of virtual water trade flows, 1965-2010

\begin{tabular}{|c|c|c|c|c|c|}
\hline Country & Green water & Blue water & Country & Green water & Blue water \\
\hline Albania & $\underline{2.4}$ & 21.9 & Rep. of Korea & 37.9 & 53.6 \\
\hline Algeria & 43.3 & 27.3 & Madagascar & 28.3 & $\underline{8.4}$ \\
\hline Argentina & 24.3 & 23.3 & Malawi & 25.5 & 61.8 \\
\hline Australia & 43.7 & 57.7 & Malaysia & 18.1 & 48.9 \\
\hline Austria & 38.1 & 41.8 & Malta & 33.8 & 27.1 \\
\hline Barbados & 40.8 & 49.4 & Mexico & 78.1 & 85.0 \\
\hline Belgium-Lux. & 58.1 & 46.7 & Morocco & 47.7 & 45.4 \\
\hline Bolivia & 31.8 & 27.2 & Netherlands & 44.1 & 41.7 \\
\hline Brazil & 54.8 & 41.7 & New Zealand & 40.0 & 42.7 \\
\hline Bulgaria & 29.0 & 47.5 & Nicaragua & 61.5 & 80.7 \\
\hline Cameroon & 30.7 & 14.2 & Nigeria & 59.4 & 38.1 \\
\hline Canada & 81.2 & 86.0 & Norway & 53.4 & 46.1 \\
\hline Cent.African Rep. & 25.8 & 19.2 & Pakistan & 22.9 & $\underline{4.1}$ \\
\hline Sri Lanka & 32.3 & 38.1 & Paraguay & 45.6 & 47.0 \\
\hline Chile & 49.0 & 37.9 & Peru & 63.7 & 61.9 \\
\hline China & 25.4 & 13.8 & Philippines & 56.0 & 51.9 \\
\hline Colombia & 47.5 & 69.2 & Poland & 15.7 & 20.7 \\
\hline Costa Rica & 65.2 & 57.5 & Portugal & 56.3 & 17.5 \\
\hline Czechoslovakia & $\underline{8.7}$ & 13.5 & Romania & 25.4 & 29.4 \\
\hline Denmark & 30.3 & 31.2 & Senegal & 50.1 & 44.7 \\
\hline Ecuador & 36.9 & 57.6 & Singapore & 55.4 & 58.2 \\
\hline El Salvador & 63.5 & 66.7 & Spain & 50.7 & 47.2 \\
\hline Finland & 54.1 & 41.1 & Sudan & 35.8 & 67.5 \\
\hline France & 41.0 & 29.5 & Sweden & 45.6 & 44.0 \\
\hline Germany & 28.3 & 12.9 & Switzerland & 41.3 & 34.8 \\
\hline Greece & 44.3 & 41.5 & Thailand & 44.7 & 49.9 \\
\hline Guatemala & 65.8 & 77.3 & Togo & 16.5 & 16.4 \\
\hline Honduras & 62.4 & 61.0 & Trinidad Tobago & 62.7 & 71.5 \\
\hline Hungary & $\underline{10.8}$ & 22.6 & Tunisia & 30.1 & 30.9 \\
\hline Iceland & 17.6 & 46.1 & Turkey & 29.3 & 53.6 \\
\hline India & $\underline{10.4}$ & $\underline{8.8}$ & Fmr USSR & $\underline{3.6}$ & $\underline{10.0}$ \\
\hline Indonesia & 41.9 & 48.0 & Egypt & 53.4 & 50.4 \\
\hline Ireland & 39.7 & 47.8 & United Kingdom & 42.3 & 53.9 \\
\hline Israel & 29.4 & 40.4 & USA & 54.3 & 64.2 \\
\hline Italy & 54.5 & 41.5 & Uruguay & 52.9 & 30.3 \\
\hline Japan & 76.4 & 65.5 & Venezuela & 32.6 & 61.4 \\
\hline Jordan & 19.5 & 33.1 & Fmr Yugoslavia & 20.7 & 10.7 \\
\hline
\end{tabular}

Note: The highest values are highlighted in bold, whereas the smallest ones are underlined. Source: own elaboration using trade data from United Nations Statistics Division (UN, 2013) and water footprints from Mekonnen and Hoekstra $(2011,2012)$.

In order to go into the structural changes in the virtual water transfers in more detail, a similarity index is calculated in Table SI2. The similarity index proposed by Le Masne (1988) allows us to have a first glimpse of the similarity (or changes) in the patterns/structure of water flows for each country, in different periods. This index is defined as $100 *\left[1-0.5 *\left(\sum_{c}|V W X(c, z, 2010)-V W X(c, z, 1965)|\right)\right]$ and ranges between 0 and 100 . The closer the index is to 100, the less the difference between the two periods, and thus the greater the similarity. On the basis of this index, a remarkable structural change in terms of commercial partners of countries took place between 1965 and 2010. Only certain areas - Guatemala, Nicaragua, Mexico and Canada - display a 
similarity index higher than 75 for blue water. As for green water, Japan, Mexico and Canada have the largest rating, while India, the Former Soviet Union, and Hungary have notably changed their commercial partners concerning virtual water, showing low values of the Le Masne Index. Moreover, China, one of the largest importers of water in the world, has a similarity index of 25 and 14 for green and blue water respectively, indicating a clear reorientation of its imports. In 1965, China imported more than $80 \%$ of blue water from Pakistan, Egypt and Sudan. This picture had changed radically by 2010, when $43 \%$ of blue water came from United States and $25 \%$ from India. Likewise, India changed its trade patterns throughout the period, with a similarity index around 8 for blue water. In 1965, 95\% of blue water resources consumed in India had their origin in Pakistan, while today India imports more than 50\% from the USA and Egypt, and only $5 \%$ from Pakistan. If we look at the USA, outstanding as an exporter of virtual water, its similarity index is 54 and 64 for green and blue water, respectively, indicating a smooth structural change. Most blue water was imported from Mexico in both years. 
Table SI3: Water availability, withdrawal, Gross VWM, Gross VWX and Net VWM in 1965

\begin{tabular}{|c|c|c|c|c|c|c|c|c|c|}
\hline Country & $\begin{array}{l}\text { Population } \\
\text { (000 hab.) }\end{array}$ & $\begin{array}{l}\text { Water } \\
\text { avail. } \\
\left(\mathbf{k m}^{3}\right)\end{array}$ & $\begin{array}{l}\text { Water } \\
\text { with. } \\
\left(\mathrm{km}^{3}\right)\end{array}$ & $\begin{array}{l}\text { Gross } \\
\text { VWM } \\
\left(\mathbf{k m}^{3}\right) \\
\end{array}$ & $\begin{array}{l}\text { Gross } \\
\text { VWX } \\
\left(\mathrm{km}^{3}\right)\end{array}$ & $\begin{array}{c}\text { Net } \\
\text { VWM } \\
\left(\mathrm{km}^{3}\right)\end{array}$ & $\begin{array}{c}\text { Scar. } \\
\text { Index } \\
(\%)\end{array}$ & $\begin{array}{c}\text { SS } \\
\text { index } \\
(\%) \\
\end{array}$ & $\begin{array}{c}\text { Dep. } \\
\text { index } \\
(\%)\end{array}$ \\
\hline USA & 194,303 & 3,069 & 517.7 & 53.9 & 92.5 & -38.6 & 6 & 100 & 0 \\
\hline Argentina & 22,283 & 814 & 27.6 & 1.5 & 44.1 & -42.5 & 29 & 100 & 0 \\
\hline Brazil & 83,093 & 8,233 & 35.0 & 7.2 & 34.4 & -27.2 & 235 & 100 & 0 \\
\hline Canada & 20,071 & 2,902 & 42.2 & 11.4 & 23.1 & -11.6 & 69 & 100 & 0 \\
\hline Australia & 11,439 & 492 & n.a. & 1.0 & 19.4 & -18.4 & n.a. & 100 & 0 \\
\hline Indonesia & 105,913 & 2,019 & 74.3 & 0.6 & 4.5 & -3.8 & 27 & 100 & 0 \\
\hline Thailand & 32,062 & 439 & n.a. & 0.6 & 10.3 & -9.7 & n.a. & 100 & 0 \\
\hline Malaysia & 9,648 & 580 & 10.1 & 3.8 & 1.2 & 2.6 & 57 & 79 & 21 \\
\hline New Zealand & 2,640 & 327 & 1.2 & 1.0 & 7.9 & -6.8 & 273 & 100 & 0 \\
\hline Paraguay & 2,170 & 336 & 0.4 & 0.2 & 0.8 & -0.6 & 781 & 100 & 0 \\
\hline Hungary & 10,153 & 104 & 4.8 & 2.2 & 3.0 & -0.8 & 22 & 100 & 0 \\
\hline Colombia & 18,646 & 2,132 & n.a. & 1.0 & 8.5 & -7.6 & n.a. & 100 & 0 \\
\hline Guatemala & 4,746 & 111 & n.a. & 0.4 & 2.5 & -2.1 & n.a. & 100 & 0 \\
\hline Cameroon & 6,104 & 286 & 0.4 & 0.1 & 1.4 & -1.3 & 714 & 100 & 0 \\
\hline Bolivia & 3,853 & 623 & 1.2 & 0.4 & 0.1 & 0.3 & 502 & 80 & 20 \\
\hline Nicaragua & 1,750 & 197 & n.a. & 0.2 & 2.7 & -2.5 & n.a. & 100 & 0 \\
\hline India & 485,000 & 1,911 & 438.3 & 1.3 & 12.6 & -11.3 & 4 & 100 & 0 \\
\hline Sudan & 12,086 & 53 & 14.1 & 0.5 & 4.3 & -3.7 & 4 & 100 & 0 \\
\hline France & 49,802 & 211 & 31.0 & 24.9 & 7.7 & 17.2 & 7 & 64 & 36 \\
\hline Uruguay & 2,693 & 139 & 1 & 0 & 2 & -1.8 & 214 & 100 & 0 \\
\hline Ireland & 2,876 & 52 & 0.8 & 1.4 & 0.9 & 0.5 & 66 & 59 & 41 \\
\hline Ecuador & 5,118 & 424 & n.a. & 0.2 & 1.8 & -1.5 & n.a. & 100 & 0 \\
\hline Tunisia & 4,566 & 5 & 1.9 & 1.0 & 2.7 & -1.7 & 2 & 100 & 0 \\
\hline Madagascar & 6,070 & 337 & 16.3 & 0.3 & 2.4 & -2.1 & 21 & 100 & 0 \\
\hline Malawi & 3,914 & 17 & n.a. & 0.0 & 0.5 & -0.5 & n.a. & 100 & 0 \\
\hline Bulgaria & 8,201 & 21 & 14.2 & 1.0 & 1.5 & -0.6 & 2 & 100 & 0 \\
\hline Romania & 19,027 & 212 & 18.8 & 0.4 & 2.0 & -1.5 & 11 & 100 & 0 \\
\hline El Salvador & 3,018 & 25 & 0.7 & 0.7 & 1.0 & -0.2 & 35 & 100 & 0 \\
\hline Denmark & 4,758 & 6 & 1.1 & 5.2 & 5.0 & 0.2 & 5 & 85 & 15 \\
\hline Central African Rep. & 1,628 & 144 & n.a. & 0.0 & 2.4 & -2.4 & n.a. & 100 & 0 \\
\hline Austria & 7,271 & 78 & 3.3 & 1.6 & 0.6 & 1.0 & 23 & 76 & 24 \\
\hline Albania & 1,884 & 42 & 1.2 & 0.3 & 0.0 & 0.3 & 35 & 82 & 18 \\
\hline Finland & 4,564 & 110 & 3.7 & 2.2 & 0.3 & 1.9 & 30 & 67 & 33 \\
\hline Senegal & 3,744 & 39 & 1.4 & 0.9 & 2.3 & -1.4 & 29 & 100 & 0 \\
\hline Greece & 8,550 & 74 & 5.0 & 3.1 & 0.9 & 2.3 & 15 & 69 & 31 \\
\hline Norway & 3,723 & 382 & 2.0 & 3.0 & 0.1 & 2.9 & 191 & 41 & 59 \\
\hline Sweden & 7,734 & 174 & 4.1 & 4.8 & 0.8 & 4.0 & 42 & 51 & 49 \\
\hline Poland & 31,262 & 62 & 15.1 & 7.2 & 2.9 & 4.2 & 4 & 78 & 22 \\
\hline Philippines & 33,268 & 479 & n.a. & 3.2 & 8.2 & -5.1 & n.a. & 100 & 0 \\
\hline Peru & 11,467 & 1,913 & 19.0 & 3.0 & 2.1 & 0.9 & 101 & 95 & 5 \\
\hline Jordan & 1,061 & 1 & 0.5 & 0.5 & 0.0 & 0.5 & 2 & 53 & 47 \\
\hline Pakistan & 57,495 & 247 & 155.6 & 0.0 & 0.0 & 0.0 & 2 & 100 & 0 \\
\hline Chile & 8,510 & 922 & 20.3 & 2.3 & 0.2 & 2.1 & 45 & 91 & 9 \\
\hline Venezuela & 9,068 & 1,233 & 4.1 & 2.4 & 1.4 & 1.0 & 301 & 80 & 20 \\
\hline Israel & 2,578 & 2 & 1.7 & 3.1 & 0.3 & 2.8 & 1 & 38 & 62 \\
\hline Portugal & 9,129 & 69 & n.a. & 1.7 & 0.3 & 1.4 & n.a. & n.a. & n.a. \\
\hline Nigeria & 48,064 & 286 & 3.6 & 0.4 & 0.2 & 0.2 & 79 & 94 & 6 \\
\hline Morocco & 14,066 & 29 & 10.1 & 1.9 & 1.9 & -0.1 & 3 & 100 & 0 \\
\hline Turkey & 31,951 & 212 & 31.6 & 1.2 & 3.9 & -2.7 & 7 & 100 & 0 \\
\hline Spain & 32,085 & 112 & 39.9 & 8.1 & 3.0 & 5.1 & 3 & 89 & 11 \\
\hline Algeria & 11,963 & 12 & 3.0 & 1.2 & 2.5 & -1.3 & 4 & 100 & 0 \\
\hline United Kingdom & 54,350 & 147 & 13.5 & 47.6 & 1.3 & 46.2 & 11 & 23 & 77 \\
\hline Egypt & 30,265 & 57 & 48.2 & 7.2 & 2.8 & 4.4 & 1 & 92 & 8 \\
\hline China & 715,185 & 2,840 & 443.7 & 9.2 & 8.2 & 1.0 & 6 & 100 & 0 \\
\hline Rep. of Korea & 28,705 & 70 & n.a. & 2.8 & 0.1 & 2.7 & n.a. & n.a. & n.a. \\
\hline Netherlands & 12,292 & 91 & 9.2 & 31.1 & 7.9 & 23.2 & 10 & 28 & 72 \\
\hline Mexico & 45,142 & 457 & 56 & 1 & 14 & -13.4 & 8 & 100 & 0 \\
\hline Italy & 51,987 & 191 & 41.6 & 37.9 & 2.2 & 35.7 & 5 & 54 & 46 \\
\hline Japan & 98,883 & 430 & 88 & 46 & 0 & 46.3 & 5 & 66 & 34 \\
\hline
\end{tabular}

Water avail.: water availability, Water with.: water withdrawal, VWM: green and blue virtual water imports, VWX: green and blue virtual water exports, Scar. Index: Scarcity index, SS index: Self-sufficiency index, Dep.Index: Dependency index. Source: own elaboration using trade data from United Nations Statistics Division (UN, 2013) and water footprints from Mekonnen and Hoekstra (2011, 2012). 
. Population data stem from World Bank (2014). Water availability and withdrawal come from FAO (2014).

Table SI4: Water availability, withdrawal, Gross VWM, Gross VWX and Net VWM in 1980

\begin{tabular}{|c|c|c|c|c|c|c|c|c|c|}
\hline Country & $\begin{array}{c}\text { Population } \\
\text { (000 hab.) }\end{array}$ & $\begin{array}{l}\text { Water } \\
\text { avail. } \\
\left(\mathrm{km}^{3}\right)\end{array}$ & $\begin{array}{l}\text { Water } \\
\text { with. } \\
\left(\mathbf{k m}^{3}\right)\end{array}$ & $\begin{array}{l}\text { Gross } \\
\text { VWM } \\
\left(\mathrm{km}^{3}\right)\end{array}$ & $\begin{array}{l}\text { Gross } \\
\text { VWX } \\
\left(\mathrm{km}^{3}\right)\end{array}$ & $\begin{array}{c}\text { Net } \\
\text { VWM } \\
\left(\mathrm{km}^{3}\right)\end{array}$ & $\begin{array}{c}\text { Scar. } \\
\text { Index } \\
(\%)\end{array}$ & $\begin{array}{c}\text { SS } \\
\text { index } \\
(\%)\end{array}$ & $\begin{array}{c}\text { Dep. } \\
\text { index } \\
(\%)\end{array}$ \\
\hline $\begin{array}{l}\text { USA } \\
\text { Argentina }\end{array}$ & $\begin{array}{l}227,726 \\
28,370\end{array}$ & $\begin{array}{l}3,069 \\
814\end{array}$ & $\begin{array}{l}517.7 \\
27.6\end{array}$ & $\begin{array}{l}55.1 \\
1.8\end{array}$ & $\begin{array}{l}230.7 \\
28.4\end{array}$ & $\begin{array}{l}-175.6 \\
-26.6\end{array}$ & $\begin{array}{l}6 \\
29\end{array}$ & $\begin{array}{l}100 \\
100\end{array}$ & $\begin{array}{l}0 \\
0\end{array}$ \\
\hline Brazil & 123,020 & 8,233 & 35.0 & 16.8 & 58.5 & -41.7 & 235 & 100 & 0 \\
\hline Canada & 24,593 & 2,902 & 42.2 & 10.0 & 33.6 & -23.6 & 69 & 100 & 0 \\
\hline Australia & 14,616 & 492 & n.a. & 1.5 & 39.8 & -38.3 & n.a. & 100 & 0 \\
\hline Indonesia & 147,490 & 2,019 & 74.3 & 11.3 & 8.9 & 2.4 & 27 & 97 & 3 \\
\hline Thailand & 47,026 & 439 & n.a. & 2.5 & 16.1 & -13.5 & n.a. & 100 & 0 \\
\hline Malaysia & 13,764 & 580 & 10.1 & 5.6 & 10.8 & -5.2 & 57 & 100 & 0 \\
\hline New Zealand & 3,170 & 327 & 1.2 & 0.6 & 9.1 & -8.5 & 273 & 100 & 0 \\
\hline Paraguay & 3,196 & 336 & 0.4 & 0.3 & 1.7 & -1.4 & 781 & 100 & 0 \\
\hline Hungary & 10,711 & 104 & 4.8 & 1.9 & 2.2 & -0.3 & 22 & 100 & 0 \\
\hline Colombia & 26,631 & 2,132 & n.a. & 2.2 & 12.8 & -10.5 & n.a. & 100 & 0 \\
\hline Guatemala & 6,650 & 111 & n.a. & 0.6 & 3.5 & -2.9 & n.a. & 100 & 0 \\
\hline Cameroon & 8,762 & 286 & 0.4 & 1.5 & 3.2 & -1.7 & 714 & 100 & 0 \\
\hline Bolivia & 5,441 & 623 & 1.2 & 1.1 & 0.6 & 0.5 & 502 & 73 & 27 \\
\hline Nicaragua & 2,805 & 197 & n.a. & 0.6 & 1.8 & -1.2 & n.a. & 100 & 0 \\
\hline India & 679,000 & 1,911 & 438.3 & 7.4 & 7.1 & 0.3 & 4 & 100 & 0 \\
\hline Sudan & 19,064 & 53 & 14.1 & 0.8 & 4.4 & -3.6 & 4 & 100 & 0 \\
\hline France & 55,110 & 211 & 31.0 & 34.6 & 19.6 & 15.0 & 7 & 67 & 33 \\
\hline Uruguay & 2,930 & 139 & 1 & 0 & 2 & -1.9 & 214 & 100 & 0 \\
\hline Ireland & 3,401 & 52 & 0.8 & 1.5 & 4.2 & -2.6 & 66 & 100 & 0 \\
\hline Ecuador & 7,920 & 424 & n.a. & 1.2 & 3.0 & -1.8 & n.a. & 100 & 0 \\
\hline Tunisia & 6,443 & 5 & 1.9 & 2.6 & 1.7 & 0.9 & 2 & 68 & 32 \\
\hline Madagascar & 8,691 & 337 & 16.3 & 0.4 & 2.4 & -2.1 & 21 & 100 & 0 \\
\hline Malawi & 6,259 & 17 & n.a. & 0.0 & 0.8 & -0.8 & n.a. & 100 & 0 \\
\hline Bulgaria & 8,844 & 21 & 14.2 & 1.0 & 0.8 & 0.2 & 2 & 99 & 1 \\
\hline Romania & 22,130 & 212 & 18.8 & 6.0 & 1.0 & 5.0 & 11 & 79 & 21 \\
\hline El Salvador & 4,566 & 25 & 0.7 & 0.6 & 0.8 & -0.2 & 35 & 100 & 0 \\
\hline Denmark & 5,123 & 6 & 1.1 & 5.4 & 4.3 & 1.1 & 5 & 49 & 51 \\
\hline Austria & 2,349 & 144 & n.a. & 0.0 & 3.8 & -3.8 & n.a. & 100 & 0 \\
\hline Albania & 7,549 & 78 & 3.3 & 1.8 & 0.7 & 1.1 & 23 & 75 & 25 \\
\hline Finland & 2,671 & 42 & 1.2 & 0.1 & 0.1 & 0.0 & 35 & 97 & 3 \\
\hline Senegal & 4,780 & 110 & 3.7 & 2.2 & 0.3 & 1.9 & 30 & 66 & 34 \\
\hline Greece & 5,787 & 39 & 1.4 & 2.1 & 1.5 & 0.7 & 29 & 67 & 33 \\
\hline Norway & 9,643 & 74 & 5.0 & 5.8 & 1.2 & 4.6 & 15 & 52 & 48 \\
\hline Sweden & 4,086 & 382 & 2.0 & 3.7 & 0.3 & 3.4 & 191 & 37 & 63 \\
\hline Poland & 8,310 & 174 & 4.1 & 4.3 & 0.6 & 3.7 & 42 & 52 & 48 \\
\hline Peru & 35,578 & 62 & 15.1 & 14.3 & 2.3 & 12.0 & 4 & 56 & 44 \\
\hline Jordan & 50,940 & 479 & n.a. & 4.0 & 12.4 & -8.4 & n.a. & 100 & 0 \\
\hline Pakistan & 17,295 & 1,913 & 19.0 & 4.2 & 1.0 & 3.2 & 101 & 85 & 15 \\
\hline Chile & 2,163 & 1 & 0.5 & 1.5 & 0.0 & 1.5 & 2 & 27 & 73 \\
\hline Venezuela & 85,219 & 247 & 155.6 & 3.2 & 6.4 & -3.3 & 2 & 100 & 0 \\
\hline Israel & 11,094 & 922 & 20.3 & 4.9 & 0.5 & 4.4 & 45 & 82 & 18 \\
\hline Portugal & 14,768 & 1,233 & 4.1 & 5.8 & 0.2 & 5.6 & 301 & 42 & 58 \\
\hline Nigeria & 3,737 & 2 & 1.7 & 3.6 & 0.7 & 2.9 & 1 & 37 & 63 \\
\hline Morocco & 9,778 & 69 & n.a. & 7.9 & 0.6 & 7.3 & n.a. & n.a. & n.a. \\
\hline Turkey & 74,821 & 286 & 3.6 & 5.1 & 0.1 & 5.1 & 79 & 42 & 58 \\
\hline Spain & 19,487 & 29 & 10.1 & 4.3 & 1.5 & 2.8 & 3 & 78 & 22 \\
\hline Algeria & 45,048 & 212 & 31.6 & 1.1 & 3.1 & -2.1 & 7 & 100 & 0 \\
\hline United Kingdom & 37,488 & 112 & 39.9 & 18.8 & 5.7 & 13.1 & 3 & 75 & 25 \\
\hline Egypt & 18,806 & 12 & 3.0 & 7.9 & 1.5 & 6.3 & 4 & 32 & 68 \\
\hline China & 56,314 & 147 & 13.5 & 24.8 & 7.0 & 17.8 & 11 & 43 & 57 \\
\hline Rep. of Korea & 42,634 & 57 & 48.2 & 16.5 & 1.6 & 14.9 & 1 & 76 & 24 \\
\hline Netherlands & 981,235 & 2,840 & 443.7 & 42.6 & 5.7 & 36.9 & 6 & 92 & 8 \\
\hline Mexico & 38,124 & 70 & n.a. & 16.2 & 0.3 & 15.9 & n.a. & n.a. & n.a. \\
\hline Italy & 14,144 & 91 & 9.2 & 58.0 & 14.8 & 43.2 & 10 & 18 & 82 \\
\hline Japan & 68,347 & 457 & 56 & 21 & 6 & 14.4 & 8 & 80 & 20 \\
\hline
\end{tabular}

Water avail.: water availability, Water with.: water withdrawal, VWM: green and blue virtual water imports, VWX: green and blue virtual water exports, Scar. Index: Scarcity index, SS index: Self-sufficiency index, Dep.Index: Dependency index. Source: own elaboration using trade data from United Nations Statistics Division (UN, 2013) and water footprints from Mekonnen and Hoekstra (2011, 2012). Population data stem from World Bank (2014). Water availability and withdrawal come from FAO (2014). 
Table SI5: Water availability, withdrawal, Gross VWM, Gross VWX and Net VWM in 2000

\begin{tabular}{|c|c|c|c|c|c|c|c|c|c|}
\hline Country & $\begin{array}{l}\text { Population } \\
\text { (000 hab.) }\end{array}$ & $\begin{array}{l}\text { Water } \\
\text { avail. } \\
\left(\mathrm{km}^{3}\right)\end{array}$ & $\begin{array}{l}\text { Water } \\
\text { with. } \\
\left(\mathbf{k m}^{3}\right)\end{array}$ & $\begin{array}{l}\text { Gross } \\
\text { VWM } \\
\left(\mathrm{km}^{3}\right)\end{array}$ & $\begin{array}{l}\text { Gross } \\
\text { VWX } \\
\left(\mathrm{km}^{3}\right)\end{array}$ & 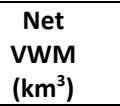 & $\begin{array}{l}\text { Scar. } \\
\text { Index } \\
(\%)\end{array}$ & $\begin{array}{c}\text { SS } \\
\text { index } \\
(\%)\end{array}$ & $\begin{array}{c}\text { Dep. } \\
\text { index } \\
(\%)\end{array}$ \\
\hline $\begin{array}{l}\text { USA } \\
\text { Argentina }\end{array}$ & $\begin{array}{r}282,158 \\
37,336\end{array}$ & $\begin{array}{l}3,069 \\
814.0\end{array}$ & $\begin{array}{r}473.4 \\
32.6\end{array}$ & $\begin{array}{l}77.2 \\
10.6\end{array}$ & $\begin{array}{r}187.6 \\
89.6\end{array}$ & $\begin{array}{r}-110.4 \\
-79.0\end{array}$ & $\begin{array}{r}6 \\
25\end{array}$ & $\begin{array}{l}100 \\
100\end{array}$ & $\begin{array}{l}0 \\
0\end{array}$ \\
\hline Brazil & 176,320 & 8233.0 & 59.3 & 27.7 & 77.0 & -49.3 & 139 & 100 & 0 \\
\hline Canada & 31,100 & 2902.0 & n.a. & 16.4 & 62.2 & -45.8 & n.a. & 100 & 0 \\
\hline Australia & 19,053 & 492.0 & 22.6 & 2.8 & 36.3 & -33.5 & 22 & 100 & 0 \\
\hline Indonesia & 205,132 & 2019.0 & 113.3 & 19.1 & 37.1 & -18.0 & 18 & 100 & 0 \\
\hline Thailand & 61,863 & 438.6 & 57.3 & 10.4 & 25.6 & -15.2 & 8 & 100 & 0 \\
\hline Malaysia & 21,804 & 580.0 & 9.3 & 14.3 & 29.4 & -15.1 & 62 & 100 & 0 \\
\hline New Zealand & 3,802 & 327.0 & 4.8 & 1.1 & 15.3 & -14.1 & 69 & 100 & 0 \\
\hline Paraguay & 5,592 & 336.0 & 0.5 & 0.7 & 8.7 & -8.0 & 686 & 100 & 0 \\
\hline Hungary & 10,137 & 104.0 & 5.8 & 1.9 & 7.2 & -5.3 & 18 & 100 & 0 \\
\hline Colombia & 39,817 & 2132.0 & 12.7 & 7.5 & 11.8 & -4.2 & 169 & 100 & 0 \\
\hline Guatemala & 11,085 & 111.3 & 2.8 & 2.4 & 5.9 & -3.5 & 40 & 100 & 0 \\
\hline Cameroon & 15,343 & 285.5 & 1.0 & 0.4 & 3.9 & -3.4 & 295 & 100 & 0 \\
\hline Bolivia & 8,195 & 622.5 & 2.6 & 1.4 & 4.6 & -3.2 & 235 & 100 & 0 \\
\hline Nicaragua & 4,935 & 196.6 & 1.4 & 0.7 & 3.4 & -2.8 & 142 & 100 & 0 \\
\hline India & $1,004,124$ & 1911.0 & 610.4 & 26.3 & 29.0 & -2.7 & 3 & 100 & 0 \\
\hline Sudan & 34,194 & 52.8 & 27.2 & 1.1 & 2.9 & -1.8 & 2 & 100 & 0 \\
\hline France & 61,137 & 211.0 & 32.4 & 31.9 & 33.5 & -1.6 & 7 & 100 & 0 \\
\hline Uruguay & 3,328 & 139 & 4 & 3 & 4.9 & -1.6 & 38 & 100 & 0 \\
\hline Ireland & 3,792 & 52.0 & n.a. & 2.5 & 4.1 & -1.5 & n.a. & 100 & 0 \\
\hline Ecuador & 12,446 & 424.4 & 9.4 & 1.9 & 3.1 & -1.2 & 45 & 100 & 0 \\
\hline Tunisia & 9,568 & 4.6 & 2.9 & 4.8 & 5.8 & -1.0 & 2 & 100 & 0 \\
\hline Madagascar & 15,742 & 337.0 & 16.5 & 0.5 & 1.4 & -1.0 & 20 & 100 & 0 \\
\hline Malawi & 11,560 & 17.3 & 1.3 & 0.0 & 0.8 & -0.8 & 13 & 100 & 0 \\
\hline Bulgaria & 7,818 & 21.3 & 5.7 & 1.4 & 2.1 & -0.8 & 4 & 100 & 0 \\
\hline Romania & 22,452 & 211.9 & 9.2 & 2.8 & 3.2 & -0.4 & 23 & 100 & 0 \\
\hline El Salvador & 6,126 & 25.2 & 1.4 & 2.0 & 2.2 & -0.2 & 18 & 100 & 0 \\
\hline Denmark & 5,337 & 6.0 & 0.7 & 7.0 & 7.1 & -0.1 & 9 & 100 & 0 \\
\hline Austria & 3,940 & 144.4 & 0.1 & 0.0 & 0.1 & 0.0 & 2,181 & 100 & 0 \\
\hline Albania & 8,113 & 77.7 & 3.7 & 3.7 & 3.3 & 0.4 & 21 & 89 & 11 \\
\hline Finland & 3,474 & 41.7 & 1.8 & 0.6 & 0.0 & 0.6 & 23 & 75 & 25 \\
\hline Senegal & 5,169 & 110.0 & 2.3 & 2.1 & 0.8 & 1.3 & 48 & 64 & 36 \\
\hline Greece & 10,678 & 38.8 & 2.2 & 2.5 & 1.1 & 1.4 & 17 & 62 & 38 \\
\hline Norway & 10,559 & 74.3 & 9.3 & 6.7 & 4.9 & 1.9 & 8 & 83 & 17 \\
\hline Sweden & 4,492 & 382.0 & 2.4 & 2.5 & 0.3 & 2.3 & 160 & 51 & 49 \\
\hline Poland & 8,872 & 174.0 & 2.7 & 3.9 & 1.1 & 2.8 & 65 & 49 & 51 \\
\hline Peru & 38,654 & 61.6 & 12.9 & 6.5 & 3.6 & 2.9 & 5 & 82 & 18 \\
\hline Jordan & 81,222 & 479.0 & 78.9 & 12.6 & 9.3 & 3.3 & 6 & 96 & 4 \\
\hline Pakistan & 26,087 & 1913.0 & 19.3 & 5.4 & 2.0 & 3.5 & 99 & 85 & 15 \\
\hline Chile & 4,999 & 0.9 & 0.9 & 4.1 & 0.0 & 4.0 & 1 & 19 & 81 \\
\hline Venezuela & 146,405 & 246.8 & 172.6 & 9.8 & 4.9 & 4.8 & 1 & 97 & 3 \\
\hline Israel & 15,156 & 922.0 & 24.7 & 6.2 & 1.3 & 4.9 & 37 & 83 & 17 \\
\hline Portugal & 23,493 & 1233.0 & 9.1 & 6.6 & 1.0 & 5.6 & 136 & 62 & 38 \\
\hline Nigeria & 6,115 & 1.8 & 1.8 & 6.8 & 0.7 & 6.1 & 1 & 23 & 77 \\
\hline Morocco & 10,336 & 68.7 & 8.5 & 9.7 & 3.1 & 6.6 & 8 & 56 & 44 \\
\hline Turkey & 123,179 & 286.2 & 10.3 & 6.7 & 0.0 & 6.7 & 28 & 60 & 40 \\
\hline Spain & 30,184 & 29.0 & 12.6 & 8.6 & 1.4 & 7.1 & 2 & 64 & 36 \\
\hline Algeria & 67,329 & 211.6 & 42.0 & 14.3 & 6.9 & 7.5 & 5 & 85 & 15 \\
\hline United Kingdom & 40,016 & 111.5 & 36.0 & 29.0 & 20.7 & 8.3 & 3 & 81 & 19 \\
\hline Egypt & 30,429 & 11.7 & 5.7 & 10.1 & 0.1 & 10.0 & 2 & 36 & 64 \\
\hline China & 59,522 & 147.0 & 15.6 & 24.8 & 9.2 & 15.6 & 9 & 50 & 50 \\
\hline Rep. of Korea & 70,512 & 57.3 & 55.3 & 24.8 & 9.2 & 15.6 & 1 & 78 & 22 \\
\hline Netherlands & $1,262,645$ & 2840.0 & 554.1 & 46.7 & 22.4 & 24.4 & 5 & 96 & 4 \\
\hline Mexico & 46,839 & 69.7 & 25.5 & 31.5 & 1.3 & 30.2 & 3 & 46 & 54 \\
\hline Italy & 15,908 & 91.0 & 8.9 & 60.6 & 26.7 & 33.9 & 10 & 21 & 79 \\
\hline Japan & 99,927 & 457.2 & 73 & 50 & 14.7 & 34.8 & 6 & 68 & 32 \\
\hline
\end{tabular}

Water avail.: water availability, Water with.: water withdrawal, VWM: green and blue virtual water imports, VWX: green and blue virtual water exports, Scar. Index: Scarcity index, SS index: Self-sufficiency index, Dep.Index: Dependency index. Source: own elaboration using trade data from United Nations Statistics Division (UN, 2013) and water footprints from Mekonnen and Hoekstra $(2011,2012)$. Population data stem from World Bank (2014). Water availability and withdrawal come from FAO (2014). 
Table SI6: Change in virtual water exports and decomposition analysis at the country level, 1965-2010

\begin{tabular}{|c|c|c|c|c|c|c|c|c|c|c|}
\hline & \multicolumn{5}{|c|}{ Green virtual water exports } & \multicolumn{5}{|c|}{ Blue virtual water exports } \\
\hline & $\begin{array}{c}\text { VWE } \\
\text { change } \\
\left(\mathrm{km}^{3}\right)\end{array}$ & $\begin{array}{l}\text { SE } \\
(\%)\end{array}$ & $\begin{array}{l}\text { CE } \\
(\%)\end{array}$ & $\begin{array}{l}\mathrm{TE} \\
\text { (\%) }\end{array}$ & $\begin{array}{l}\text { IE } \\
(\%)\end{array}$ & $\begin{array}{c}\text { VWE } \\
\text { change } \\
\left(\mathrm{km}^{3}\right)\end{array}$ & $\begin{array}{l}\text { SE } \\
\text { (\%) }\end{array}$ & $\begin{array}{l}\text { CE } \\
\text { (\%) }\end{array}$ & $\begin{array}{l}\text { TE } \\
\text { (\%) }\end{array}$ & $\begin{array}{l}\text { IE } \\
\text { (\%) }\end{array}$ \\
\hline Albania & 0.07 & 115 & -90 & 46 & 30 & 0.02 & 86 & -41 & 29 & 26 \\
\hline Algeria & -1.21 & -289 & -20 & 377 & 31 & -1.44 & -267 & 19 & 321 & 27 \\
\hline Argentina & 62.74 & 230 & -53 & -47 & -30 & 1.81 & 270 & -52 & -57 & -61 \\
\hline Australia & 19.83 & 391 & -17 & -194 & -81 & 1.45 & 402 & 24 & -199 & -126 \\
\hline Austria & 3.55 & 90 & -21 & 62 & -31 & 0.11 & 76 & 12 & 45 & -33 \\
\hline Barbados & -0.47 & -306 & 2 & 370 & 34 & 0.00 & 471 & 517 & -874 & -14 \\
\hline Belgium-Lux. & 12.16 & 97 & -47 & 79 & -29 & 0.42 & 83 & -26 & 61 & -18 \\
\hline Bolivia & 5.16 & 50 & -41 & 44 & 47 & 0.04 & 55 & -42 & 67 & 20 \\
\hline Brazil & 99.94 & 173 & -52 & 63 & -84 & 0.71 & 374 & -341 & 155 & -88 \\
\hline Bulgaria & 5.01 & 156 & -9 & -48 & 1 & 0.14 & 117 & 1 & -33 & 15 \\
\hline Cameroon & 0.14 & 3982 & -307 & -3543 & -32 & 0.00 & 152 & 80 & -126 & -5 \\
\hline Canada & 58.77 & 163 & -28 & 6 & -41 & 3.23 & 76 & 27 & 2 & -4 \\
\hline Cent. African Rep. & -2.84 & -311 & 0 & 394 & 17 & 0.00 & -300 & -24 & 373 & 50 \\
\hline Sri Lanka & -0.82 & -1140 & -27 & 1126 & 141 & 0.03 & 73 & 113 & -70 & -15 \\
\hline Chile & 1.89 & 65 & -146 & 192 & -10 & 0.68 & 95 & -410 & 430 & -16 \\
\hline China & 5.28 & 492 & -394 & 201 & -199 & -0.11 & -2693 & 3190 & -1204 & 807 \\
\hline Colombia & 6.22 & 467 & -58 & -284 & -26 & 0.06 & 178 & 9 & -99 & 12 \\
\hline Costa Rica & 5.36 & 207 & -154 & 45 & 1 & 0.18 & 157 & -64 & 32 & -25 \\
\hline Czechoslovakia & 5.53 & 394 & 705 & 1452 & -2451 & 0.38 & 176 & 1403 & 558 & -2037 \\
\hline Denmark & 3.55 & 450 & -26 & -244 & -80 & 0.17 & 423 & -26 & -228 & -68 \\
\hline Ecuador & 1.42 & 502 & -339 & -47 & -17 & 0.26 & 166 & -1 & -13 & -52 \\
\hline El Salvador & 0.56 & 532 & 11 & -444 & 1 & 0.02 & 424 & 127 & -352 & -100 \\
\hline Finland & 0.76 & 188 & -4 & -24 & -60 & 0.01 & 304 & -81 & -42 & -80 \\
\hline France & 22.63 & 146 & -18 & 36 & -64 & 1.38 & 127 & 1 & 29 & -57 \\
\hline Germany & 23.57 & 76 & -15 & 66 & -27 & 0.60 & 66 & 11 & 47 & -23 \\
\hline Greece & 1.36 & 364 & -96 & -118 & -49 & 1.12 & 140 & 35 & -39 & -36 \\
\hline Guatemala & 3.57 & 278 & -73 & -18 & -87 & 0.15 & 70 & 88 & -3 & -55 \\
\hline Honduras & 4.85 & 126 & 64 & -15 & -75 & 0.03 & 458 & -230 & -68 & -61 \\
\hline Hungary & 13.93 & 121 & -53 & 40 & -9 & 0.34 & 77 & -14 & 19 & 18 \\
\hline Iceland & 0.01 & 862 & 14 & -745 & -31 & 0.00 & 6394 & -436 & -5589 & -269 \\
\hline India & 40.60 & 113 & 58 & 0 & -71 & 6.37 & 125 & 89 & 0 & -114 \\
\hline Indonesia & 88.65 & 60 & 9 & 54 & -23 & 0.38 & 128 & -235 & 233 & -26 \\
\hline Ireland & 2.52 & 175 & 4 & -30 & -49 & 0.16 & 181 & 4 & -31 & -54 \\
\hline Israel & 0.38 & 137 & 41 & -65 & -12 & 0.59 & 175 & 27 & -87 & -14 \\
\hline Italy & 12.62 & 89 & 12 & 24 & -25 & 1.54 & 101 & -8 & 29 & -22 \\
\hline Japan & 0.11 & 599 & -39 & -350 & -111 & 0.00 & 1098 & -42 & -655 & -301 \\
\hline Jordan & 0.06 & 48 & -804 & 832 & 24 & 0.03 & 43 & -90 & 99 & 48 \\
\hline Rep. of Korea & 1.10 & 67 & 9 & 62 & -38 & 0.02 & 139 & -226 & 223 & -36 \\
\hline Madagascar & -1.72 & -355 & -16 & 459 & 12 & 0.11 & 254 & 338 & -573 & 81 \\
\hline Malawi & -0.82 & -538 & 14 & 480 & 143 & 0.02 & 1119 & 197 & -968 & -248 \\
\hline Malaysia & 41.66 & 52 & 11 & 61 & -24 & 0.09 & 119 & -418 & 433 & -34 \\
\hline Malta & 0.00 & -3553 & -900 & 5238 & -684 & -0.01 & -276 & 67 & 318 & -9 \\
\hline Mexico & 2.16 & 1422 & -666 & -522 & -134 & -0.19 & -5753 & 2857 & 2171 & 825 \\
\hline Morocco & 0.19 & 2339 & -512 & -1706 & -21 & 0.03 & 1620 & -204 & -1177 & -139 \\
\hline Netherlands & 27.98 & 116 & -39 & 48 & -25 & 1.82 & 119 & -44 & 50 & -25 \\
\hline New Zealand & 10.63 & 262 & 10 & -141 & -31 & 0.73 & 284 & -5 & -154 & -25 \\
\hline Nicaragua & 2.22 & 392 & 57 & -225 & -124 & 0.06 & 118 & 44 & -57 & -5 \\
\hline Nigeria & 0.15 & 418 & -639 & 289 & 32 & 0.02 & 74 & -26 & 27 & 25 \\
\hline Norway & 0.07 & 610 & 78 & -464 & -124 & 0.00 & -3127 & 245 & 2466 & 516 \\
\hline Pakistan & 0.20 & 2554 & 214 & -2082 & -587 & 0.37 & 2889 & 350 & -2357 & -782 \\
\hline Paraguay & 20.43 & 56 & 2 & 53 & -10 & 0.11 & 62 & -73 & 75 & 36 \\
\hline
\end{tabular}




\begin{tabular}{|c|c|c|c|c|c|c|c|c|c|c|}
\hline Peru & 1.72 & 265 & 0 & -121 & -44 & -0.52 & -405 & 256 & 221 & 28 \\
\hline Philippines & 1.42 & 1578 & -116 & -1147 & -216 & -0.19 & -322 & 137 & 252 & 33 \\
\hline Poland & 7.76 & 153 & -18 & 12 & -47 & 0.15 & 225 & -74 & 20 & -71 \\
\hline Portugal & 2.73 & 83 & -17 & 20 & 14 & 0.93 & 63 & -1 & 11 & 27 \\
\hline Romania & 5.74 & 215 & -14 & -58 & -42 & 0.20 & 176 & 5 & -46 & -35 \\
\hline Senegal & -2.30 & -305 & 7 & 397 & 1 & 0.00 & 122 & 460 & -502 & 20 \\
\hline Singapore & -14.84 & -267 & 20 & 336 & 11 & -0.25 & -264 & 33 & 321 & 10 \\
\hline Spain & 19.45 & 96 & -25 & 50 & -21 & 7.30 & 80 & 3 & 36 & -19 \\
\hline Sudan & -1.63 & -373 & 28 & 426 & 19 & -1.45 & -394 & 23 & 452 & 19 \\
\hline Sweden & 0.63 & 398 & -93 & -150 & -55 & 0.01 & 424 & -130 & -160 & -33 \\
\hline Switzerland & 0.24 & 143 & -83 & 79 & -40 & 0.01 & 136 & -60 & 74 & -50 \\
\hline Thailand & 20.63 & 173 & -106 & 59 & -26 & 3.10 & 129 & -25 & 39 & -43 \\
\hline Togo & -0.02 & -3727 & 3 & 4047 & -223 & 0.00 & 109 & 71 & -130 & 50 \\
\hline Trinidad Tobago & -0.67 & -269 & 40 & 317 & 11 & -0.02 & -265 & 31 & 310 & 23 \\
\hline Tunisia & 3.54 & 212 & 41 & -124 & -29 & 0.19 & 509 & -68 & -320 & -22 \\
\hline Turkey & 3.14 & 186 & -32 & -40 & -13 & -1.44 & -486 & 377 & 136 & 73 \\
\hline Fmr USSR & 101.21 & 62 & -17 & 90 & -35 & 3.59 & 54 & 13 & 58 & -25 \\
\hline Egypt & 0.31 & 187 & 44 & -94 & -36 & -0.60 & -1351 & 504 & 805 & 142 \\
\hline United Kingdom & 6.88 & 127 & -52 & 57 & -33 & 0.13 & 511 & -619 & 301 & -92 \\
\hline USA & 85.83 & 350 & -64 & -94 & -92 & 13.46 & 281 & -37 & -74 & -70 \\
\hline Uruguay & 5.26 & 155 & -35 & 13 & -33 & 0.44 & 79 & 89 & 5 & -73 \\
\hline Venezuela & -1.00 & -332 & 23 & 371 & 38 & -0.11 & -279 & 35 & 307 & 38 \\
\hline Fmr Yugoslavia & 1.65 & 887 & -270 & -445 & -72 & -0.03 & -902 & 274 & 481 & 247 \\
\hline
\end{tabular}

VWE change: change in virtual water exports $\left(\mathrm{km}^{3)}\right.$, SE: Scale effect (\%), CE: Composition effect (\%),TE: Trade share effect (\%), IE: Intensity effect (\%). Source: own elaboration using trade data from United Nations Statistics Division (UN, 2013) and water footprints from Mekonnen and Hoekstra $(2011,2012)$. 
Table SI7: Change in virtual water imports and decomposition analysis at the country level, 1965-2010

\begin{tabular}{|c|c|c|c|c|c|c|c|c|c|c|c|c|}
\hline & \multicolumn{6}{|c|}{ Green virtual water imports } & \multicolumn{6}{|c|}{ Blue virtual water imports } \\
\hline & $\begin{array}{l}\text { VWM } \\
\text { change } \\
\left(\mathrm{km}^{3}\right)\end{array}$ & $\begin{array}{c}\text { SE } \\
(\%)\end{array}$ & $\begin{array}{c}\text { CE } \\
(\%)\end{array}$ & $\begin{array}{c}\text { TE } \\
(\%)\end{array}$ & $\begin{array}{l}\text { LE } \\
\text { (\%) }\end{array}$ & $\begin{array}{c}\text { IE } \\
(\%)\end{array}$ & $\begin{array}{l}\text { VWM } \\
\text { change } \\
\left(\mathbf{k m}^{3}\right)\end{array}$ & $\begin{array}{c}\text { SE } \\
(\%)\end{array}$ & $\begin{array}{c}\text { CE } \\
(\%)\end{array}$ & $\begin{array}{c}\text { TE } \\
\text { (\%) }\end{array}$ & $\begin{array}{l}\text { LE } \\
\text { (\%) }\end{array}$ & $\begin{array}{c}\text { IE } \\
\text { (\%) }\end{array}$ \\
\hline Albania & 0.93 & 123 & -96 & 59 & 52 & -37 & 0.07 & 86 & -36 & 34 & 41 & -26 \\
\hline Algeria & 12.87 & 95 & 19 & 36 & -2 & -47 & 0.91 & 88 & 25 & 32 & -1 & -43 \\
\hline Argentina & 2.27 & 299 & -128 & -26 & 1 & -45 & -0.01 & -2194 & 1304 & 222 & 562 & 206 \\
\hline Australia & 3.87 & 124 & -10 & 9 & 13 & -37 & 0.45 & 107 & 20 & 7 & 1 & -36 \\
\hline Austria & 6.65 & 113 & -7 & 13 & 545 & -563 & 0.28 & 221 & -117 & 33 & 795 & -832 \\
\hline Barbados & 0.07 & 663 & -542 & 88 & -16 & -93 & 0.02 & 154 & -74 & 15 & 35 & -30 \\
\hline Belgium-Lux. & 14.92 & 343 & -72 & -60 & -23 & -89 & 0.11 & 4623 & - & -1007 & -1456 & -780 \\
\hline Bolivia & 0.35 & 424 & -112 & -129 & 40 & -124 & 0.02 & 471 & 79 & -143 & -194 & -113 \\
\hline Brazil & 10.62 & 289 & -38 & -82 & 25 & -94 & 0.65 & 202 & 32 & -37 & -34 & -63 \\
\hline Bulgaria & 0.72 & 624 & -605 & 164 & 28 & -112 & 0.03 & 2592 & - & 710 & -190 & -325 \\
\hline Cameroon & 1.17 & 66 & 18 & 9 & 48 & -42 & 0.25 & 72 & 81 & 15 & -13 & -55 \\
\hline Canada & 6.71 & 447 & -57 & -198 & 2 & -95 & 1.13 & 397 & -60 & -123 & -25 & -89 \\
\hline Cent. African Rep. & 0.05 & 142 & -156 & 115 & 22 & -24 & 0.01 & 65 & 76 & 21 & -56 & -7 \\
\hline Sri Lanka & 2.09 & 395 & 96 & -261 & -49 & -80 & 0.20 & 651 & -67 & -440 & 135 & -180 \\
\hline Chile & 4.80 & 219 & 23 & -109 & 29 & -61 & 0.05 & 2085 & 95 & -1166 & -508 & -405 \\
\hline China & 142.12 & 78 & -153 & 137 & 71 & -34 & 8.10 & 82 & 0 & 150 & -72 & -60 \\
\hline Colombia & 10.38 & 69 & -99 & 142 & 18 & -31 & 0.53 & 82 & -120 & 208 & -34 & -35 \\
\hline Costa Rica & 1.48 & 100 & -22 & 115 & -52 & -40 & 0.20 & 86 & -31 & 90 & -8 & -37 \\
\hline Czechoslovakia & 2.86 & 479 & -344 & 52 & 664 & -751 & -0.65 & -438 & 466 & -53 & -55 & 180 \\
\hline Denmark & 3.25 & 517 & -20 & -236 & -63 & -98 & 0.06 & 1879 & 63 & -894 & -680 & -268 \\
\hline Ecuador & 2.88 & 68 & 11 & 35 & 12 & -26 & 0.14 & 93 & 8 & 65 & -30 & -35 \\
\hline El Salvador & 1.46 & 168 & -71 & 96 & -47 & -45 & 0.24 & 79 & -6 & 31 & 35 & -40 \\
\hline Finland & 0.92 & 916 & -313 & -307 & 7 & -204 & -0.06 & -881 & 496 & 232 & 141 & 113 \\
\hline France & 8.39 & 904 & -648 & 50 & -60 & -146 & -0.33 & -3291 & 2982 & -403 & 312 & 500 \\
\hline Germany & 63.41 & 74 & 72 & 23 & 15 & -85 & 3.63 & 87 & 46 & 39 & 16 & -88 \\
\hline Greece & 5.95 & 170 & -167 & 143 & 1 & -47 & 0.19 & 567 & -867 & 591 & -83 & -108 \\
\hline Guatemala & 2.26 & 91 & 8 & 65 & -35 & -29 & 0.33 & 62 & 28 & 31 & 10 & -30 \\
\hline Honduras & 1.14 & 97 & -9 & 97 & -44 & -41 & 0.23 & 64 & 0 & 41 & 29 & -34 \\
\hline Hungary & 1.52 & 482 & -285 & -22 & 575 & -651 & -0.18 & -681 & 599 & 35 & -231 & 377 \\
\hline Iceland & -0.01 & -4536 & 2644 & 1130 & 89 & 774 & 0.00 & -1338 & 1934 & -984 & 319 & 169 \\
\hline India & 43.30 & 53 & -77 & 96 & 46 & -18 & 0.63 & 221 & - & 1401 & 14 & -43 \\
\hline Indonesia & 26.92 & 53 & -6 & 63 & 27 & -37 & 2.22 & 86 & -201 & 230 & 39 & -53 \\
\hline Ireland & 2.81 & 184 & -131 & 106 & -6 & -53 & 0.20 & 219 & -141 & 131 & -50 & -59 \\
\hline Israel & 4.99 & 228 & -30 & -63 & 30 & -65 & 0.30 & 358 & -72 & -104 & -14 & -68 \\
\hline Italy & 22.64 & 561 & -84 & -222 & -24 & -131 & 1.11 & 796 & -204 & -321 & -44 & -127 \\
\hline Japan & 22.07 & 649 & -127 & -279 & -10 & -133 & -1.21 & -1538 & 688 & 705 & -3 & 247 \\
\hline Jordan & 3.41 & 166 & -170 & 142 & -1 & -37 & 0.28 & 290 & -399 & 282 & -17 & -56 \\
\hline Rep. of Korea & 29.36 & 73 & -34 & 73 & 31 & -43 & 1.86 & 121 & -136 & 177 & -10 & -52 \\
\hline Madagascar & 0.27 & 340 & -633 & 497 & -44 & -60 & 0.20 & 133 & -224 & 142 & 135 & -86 \\
\hline Malawi & 0.17 & 102 & 106 & -49 & -3 & -55 & 0.00 & 175 & 58 & -84 & 11 & -60 \\
\hline Malaysia & 5.90 & 962 & -168 & -621 & 49 & -122 & 0.46 & 571 & -287 & -42 & -32 & -109 \\
\hline Malta & -0.01 & - & 51498 & -39491 & -7744 & 10303 & 0.03 & 346 & - & 1529 & 246 & -237 \\
\hline Mexico & 39.75 & 47 & 19 & 57 & 7 & -30 & 4.95 & 48 & 21 & 63 & -2 & -30 \\
\hline Morocco & 8.15 & 139 & -213 & 225 & 12 & -63 & 0.54 & 128 & -107 & 129 & -12 & -38 \\
\hline Netherlands & 35.29 & 297 & -90 & -29 & -1 & -77 & 0.54 & 1395 & -622 & -143 & -221 & -309 \\
\hline New Zealand & 2.07 & 153 & -69 & 34 & 21 & -40 & 0.12 & 374 & -267 & 108 & -33 & -82 \\
\hline Nicaragua & 0.64 & 156 & -110 & 131 & -30 & -47 & 0.13 & 105 & -69 & 73 & 29 & -39 \\
\hline Nigeria & 9.94 & 58 & -3 & 58 & 25 & -38 & 0.99 & 51 & 107 & 36 & -58 & -37 \\
\hline Norway & -0.56 & -1956 & 583 & 1134 & -32 & 371 & -0.05 & -1067 & 405 & 469 & 117 & 176 \\
\hline Pakistan & 41.66 & 43 & 16 & 30 & 42 & -32 & 4.28 & 44 & -55 & 83 & 81 & -53 \\
\hline Paraguay & 0.14 & 719 & -1361 & 823 & 52 & -132 & 0.03 & 115 & -47 & 85 & -29 & -24 \\
\hline Peru & 5.08 & 234 & 6 & -81 & -8 & -51 & 0.24 & 318 & 43 & -113 & -47 & -101 \\
\hline Philippines & 11.53 & 120 & -5 & 17 & 11 & -43 & 0.72 & 265 & -133 & 46 & 5 & -83 \\
\hline Poland & 6.43 & 344 & -149 & -18 & 198 & -275 & -0.34 & -954 & 686 & 57 & -59 & 370 \\
\hline Portugal & 10.16 & 106 & -62 & 99 & 2 & -45 & 1.58 & 103 & -93 & 99 & 25 & -34 \\
\hline
\end{tabular}




\begin{tabular}{|c|c|c|c|c|c|c|c|c|c|c|c|c|}
\hline Romania & 7.01 & 58 & 7 & 22 & 36 & -23 & 0.03 & 3823 & - & 4166 & -920 & -469 \\
\hline Senegal & 1.59 & 220 & -170 & 112 & 4 & -66 & 0.34 & 198 & -161 & 108 & 39 & -84 \\
\hline Singapore & 6.69 & 238 & -43 & -61 & 14 & -48 & 0.12 & 1352 & -611 & -476 & 78 & -242 \\
\hline Spain & 28.01 & 147 & -3 & 8 & 1 & -54 & 1.94 & 178 & -61 & 22 & -9 & -30 \\
\hline Sudan & 2.91 & 142 & -12 & 22 & -6 & -47 & 0.29 & 143 & -31 & 35 & 1 & -47 \\
\hline Sweden & 0.07 & 22122 & -3455 & -13412 & -1336 & -3819 & 0.03 & 2836 & -208 & -1890 & -296 & -342 \\
\hline Switzerland & -1.76 & -1026 & 281 & 702 & -23 & 165 & -0.62 & -402 & 236 & 169 & 54 & 44 \\
\hline Thailand & 13.60 & 57 & 37 & 6 & 47 & -48 & 1.11 & 69 & 60 & 0 & 26 & -56 \\
\hline Togo & 0.99 & 52 & -8 & 36 & 51 & -30 & 0.18 & 50 & 38 & 36 & 27 & -50 \\
\hline Trinidad Tobago & 0.30 & 497 & -199 & -112 & 6 & -93 & 0.04 & 237 & -37 & -44 & 2 & -59 \\
\hline Tunisia & 5.06 & 117 & -15 & 24 & 18 & -44 & 0.37 & 111 & -22 & 24 & 27 & -40 \\
\hline Turkey & 22.39 & 54 & -67 & 98 & 49 & -34 & 2.58 & 52 & 107 & 79 & -107 & -31 \\
\hline Fmr USSR & 58.37 & 51 & -79 & 97 & 59 & -27 & 2.60 & 127 & -833 & 854 & 0 & -48 \\
\hline Egypt & 27.31 & 145 & -53 & 46 & 13 & -51 & 1.28 & 197 & -94 & 67 & -17 & -53 \\
\hline United Kingdom & -13.43 & -863 & 94 & 733 & 31 & 105 & -2.18 & -626 & 71 & 535 & 48 & 73 \\
\hline USA & 28.55 & 601 & -209 & -206 & 23 & -110 & 2.27 & 522 & -119 & -177 & -45 & -81 \\
\hline Uruguay & 4.11 & 70 & -44 & 93 & 2 & -21 & 0.03 & 303 & -954 & 819 & 4 & -71 \\
\hline Venezuela & 12.63 & 99 & -14 & 36 & -2 & -20 & 0.58 & 153 & -10 & 64 & -60 & -48 \\
\hline Fmr Yugoslavia & 7.23 & 96 & -3 & 84 & -7 & -69 & 0.19 & 272 & -367 & 420 & -127 & -98 \\
\hline
\end{tabular}

VWM change: change in virtual water imports ( $\left.\mathrm{km}^{3}\right)$, SE: Scale effect (\%), CE: Composition effect (\%), LE: localization effect (\%), TE: Trade share effect (\%), IE: Intensity effect (\%). Source: own elaboration using trade data from United Nations Statistics Division (UN, 2013) and water footprints from Mekonnen and Hoekstra (2011, 2012). 
Figure SI1: Country net exports of blue water and top five net flows in the world, 1980. Source: own elaboration using trade data from United Nations Statistics Division (UN, 2013) and water footprints from Mekonnen and Hoekstra (2011, 2012).

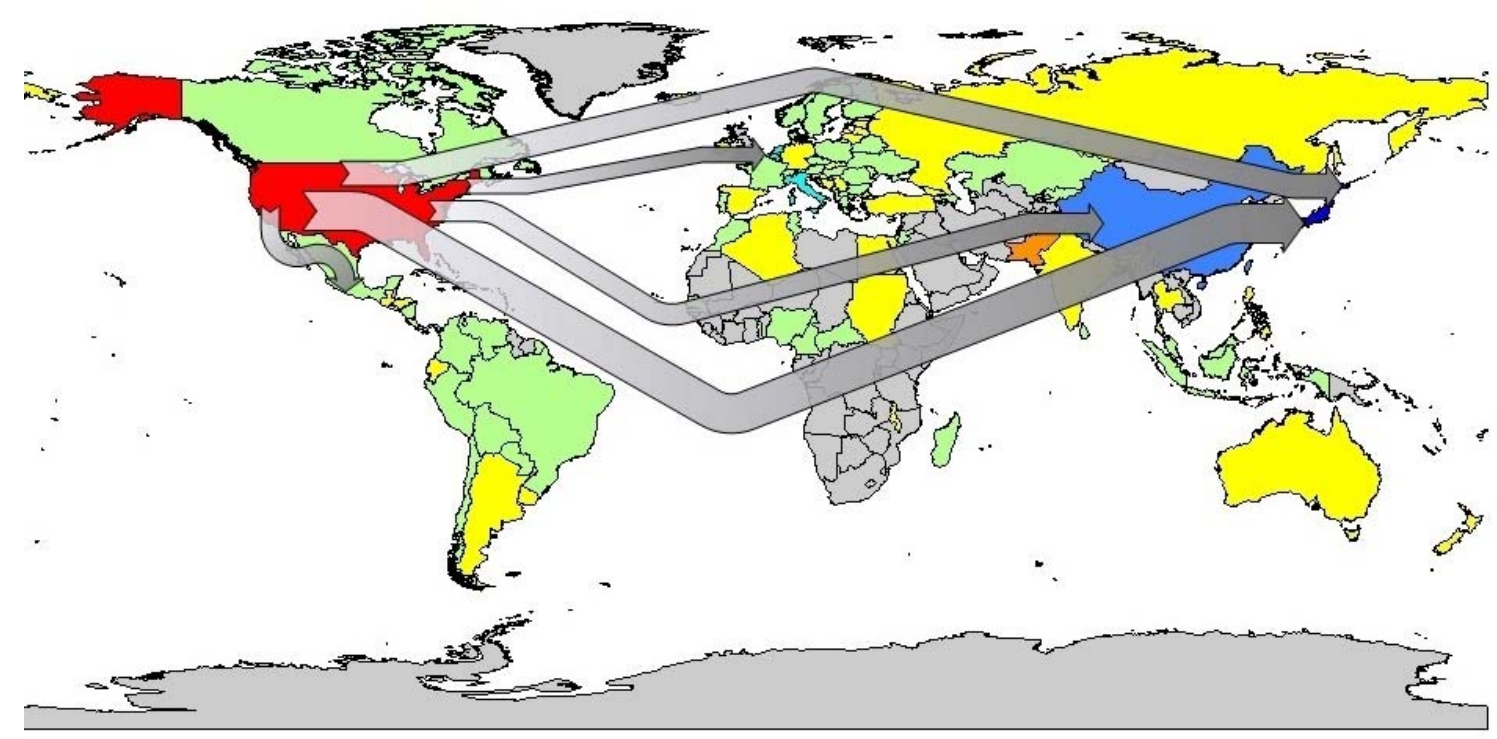

Thousand cubic meters

$-7437--5925$

Figure SI2: Country net exports of green water and top five net flows in the world, 1965. Source: own elaboration using trade data from United Nations Statistics Division (UN, 2013) and water footprints from Mekonnen and Hoekstra (2011, 2012).

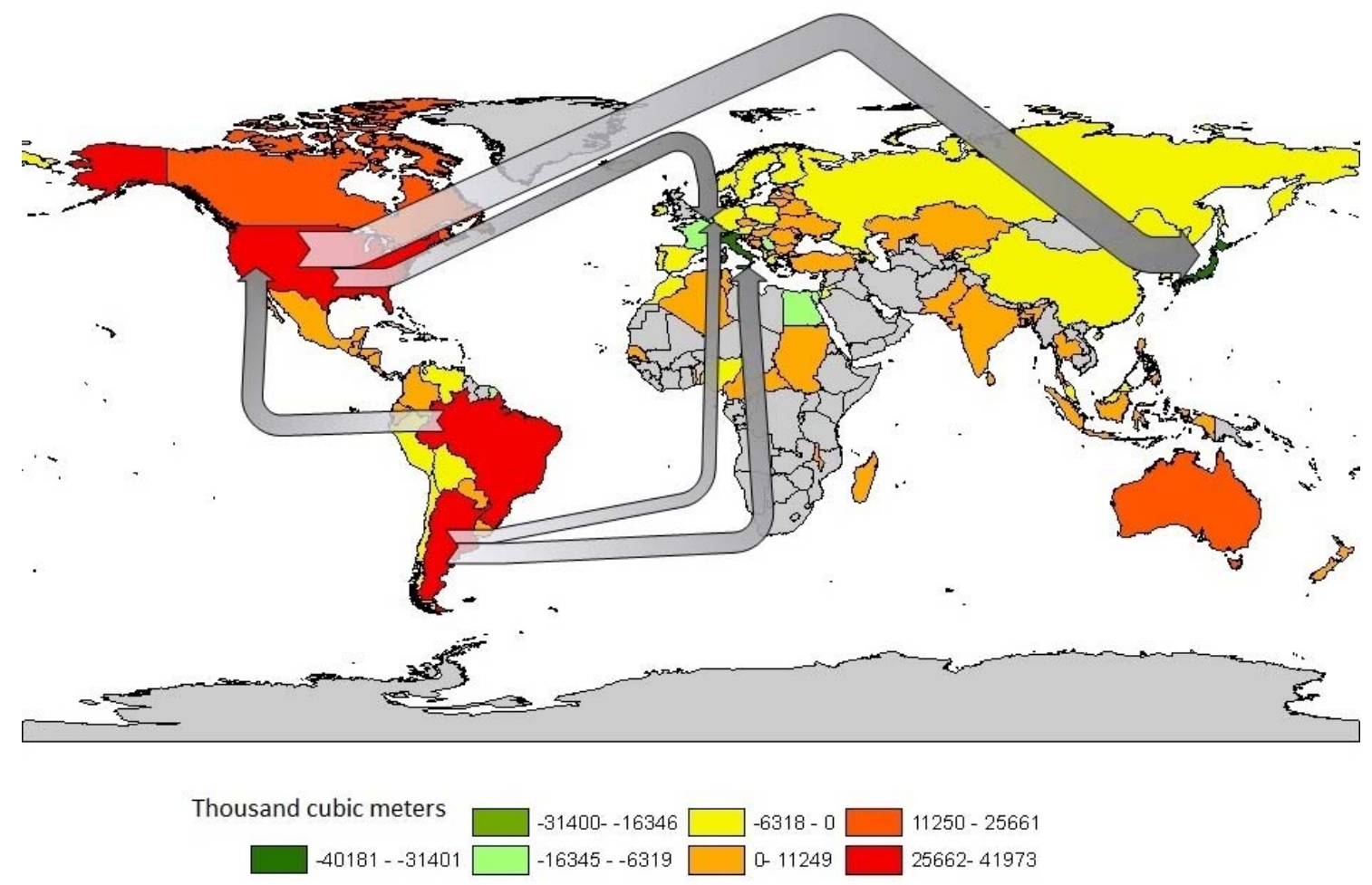


Figure SI3: Country net exports of green water and top five net flows in the world, 1980. Source: own elaboration using trade data from United Nations Statistics Division (UN, 2013) and water footprints from Mekonnen and Hoekstra (2011, 2012).

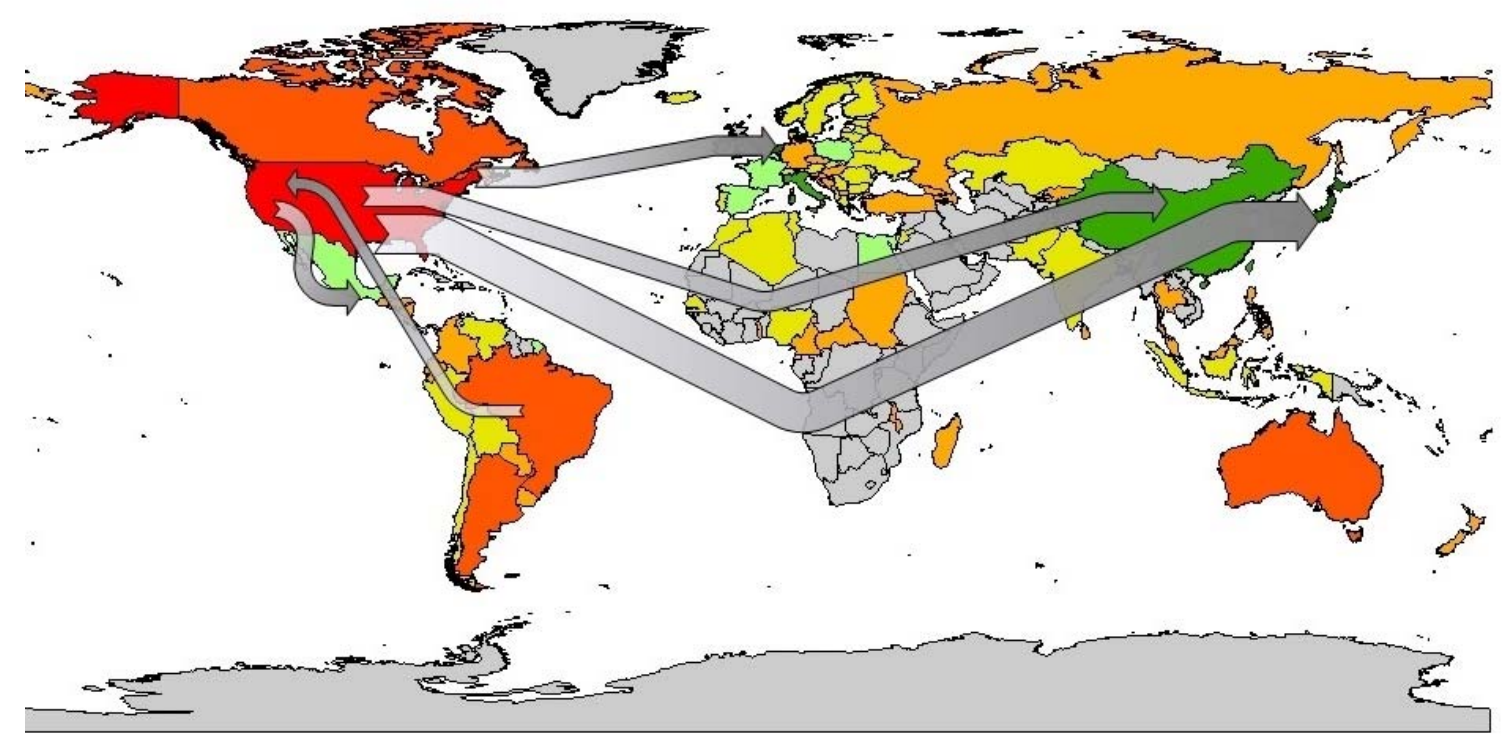

Thousand cubic meters

$-72200--39365$

$-39364--23809$ $-23808--8254$

$-8253-0$

$0-17159$

$17160-90856$

$90857-152097$ 
Figure SI4: Country net exports of green water and top five net flows in the world, 2010. Source: own elaboration using trade data from United Nations Statistics Division (UN, 2013) and water footprints from Mekonnen and Hoekstra (2011, 2012).

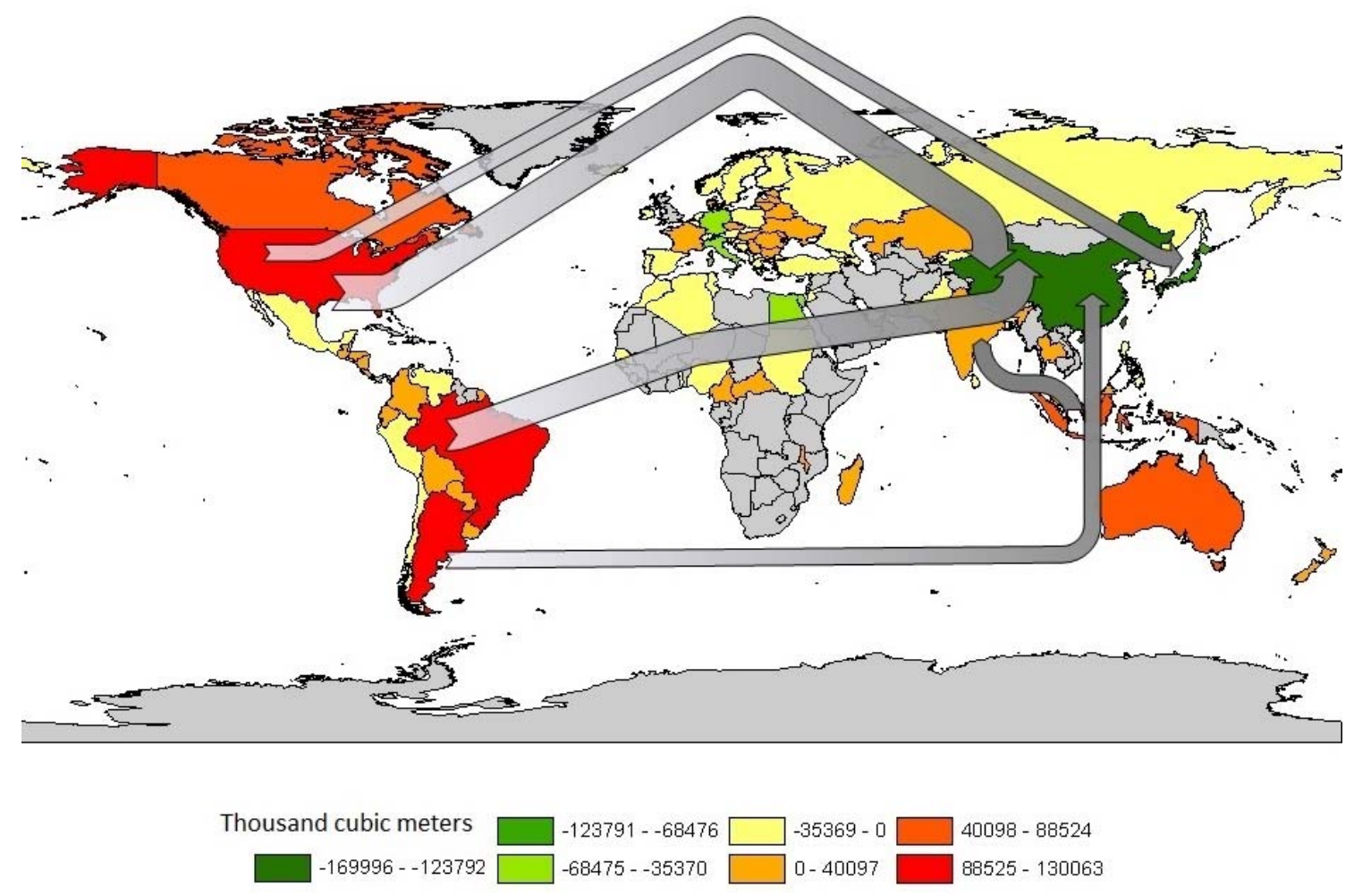

\section{List of products}

\begin{tabular}{|c|c|c|}
\hline $\begin{array}{l}\text { SITC } \\
\text { rev. } 1\end{array}$ & Group & Product \\
\hline 00 & Live animals & $\begin{array}{l}\text { Bovine cattle including buffaloes } \\
\text { Sheep,lambs and goats } \\
\text { Swine } \\
\text { Poultry, live } \\
\text { Horses, asses, mules and hinnies }\end{array}$ \\
\hline 01 & Meat and meat preparations & $\begin{array}{l}\text { Meat of bovine animals, fresh,chilled or frozen } \\
\text { Meat of sheep \& goats, fresh, chilled or frozen } \\
\text { Meat of swine,fresh,chilled or frozen } \\
\text { Meat of horses,asses,mules \& hinnies,fr.ch.fro. } \\
\text { Edible offal of animals,fresh,chilled,frozen } \\
\text { Bacon,ham \& other dried,salted,smoked pig } \\
\text { Meat \& edible offal. Dried,salted,smoked } \\
\text { Other prepared or preserved meat }\end{array}$ \\
\hline 02 & Dairy products and eggs & $\begin{array}{l}\text { Milk \& cream evaporated or condensed } \\
\text { Milk \& cream in solid form, blocks or powder } \\
\text { Milk \& cream fresh } \\
\text { Butter } \\
\text { Cheese and curd } \\
\text { Eggs }\end{array}$ \\
\hline 04 & Cereals and cereal preparations & $\begin{array}{l}\text { Wheat and meslin, unmilled } \\
\text { Rice in the husk or not, not further prepared } \\
\text { Rice, glazed or polished, not further prepared } \\
\text { Barley, unmilled }\end{array}$ \\
\hline
\end{tabular}




\begin{tabular}{|c|c|c|}
\hline & & $\begin{array}{l}\text { Maize corn unmilled } \\
\text { Rye,unmilled } \\
\text { Oats, unmilled } \\
\text { Cereals, unmilled,nes } \\
\text { Malt including malt flour } \\
\text { Flour of wheat or of meslin } \\
\text { Meal \& groats of wheat or of meslin } \\
\text { Cereal flours exc.of wheat or of meslin } \\
\text { Cereal meal \& groats exc. Of wheat or meslin } \\
\text { Cereal grains,rolled,flaked,polished }\end{array}$ \\
\hline 05 & Fruits and vegetables & $\begin{array}{l}\text { Oranges, tangerines and clementines } \\
\text { Other citrus fruit } \\
\text { Bananas including plantains, fresh } \\
\text { Apples, fresh } \\
\text { Grapes,fresh } \\
\text { Fruit juices \& vegetable juices, unfermented } \\
\text { Potatoes, fresh, not including sweet potatoes } \\
\text { Beans,peas,lentils \& leguminous vegetab.,dried } \\
\text { Tomatoes, fresh } \\
\text { Other fresh vegetables } \\
\text { Vegetables, dehydrated excl.leguminous vegetab. } \\
\text { Other edible nuts,fresh or dried } \\
\text { Pears \& quinces,fresh } \\
\text { Stone fruit,fresh } \\
\text { Berries, fresh } \\
\text { Tropical fruit other than bananas,fresh } \\
\text { Other fresh fruit } \\
\text { Tropical fruit,dried } \\
\text { Figs,dried } \\
\text { Grapes,dried (raisins) } \\
\text { Other dried fruit } \\
\text { Fruit pres. By freezing, not cont. Added sugar } \\
\text { Fruit in temporary preservative } \\
\text { Peel of melons \& citrus fruit not pres by sugar } \\
\text { Vegetables,frozen } \\
\text { Vegetables in temporary preservative } \\
\text { Roots \& tubers,fresh or dried,sago pith } \\
\text { Sugar beet,fresh or dried;sugar cane } \\
\text { Hops } \\
\text { Vegetable products,fresh or dried,n.e.s. } \\
\text { Flours of the fruits falling within group 051 } \\
\text { Flour,meal \& flakes of potato }\end{array}$ \\
\hline 06 & Sugar, sugar preparations and honey & $\begin{array}{l}\text { Raw sugar,beet \& cane } \\
\text { Refined sugar \& other prod.of refining,no syrup } \\
\text { Molasses } \\
\text { Sugars \& syrups nes incl.art.honey \& caramel }\end{array}$ \\
\hline 07 & Coffee, tea, cocoa, spices \& manufacs. & $\begin{array}{l}\text { Coffee,green or roasted } \\
\text { Tea } \\
\text { Pepper \& pimento,whether or not grond } \\
\text { Vanilla } \\
\text { Cinnamon \& cinnamon tree flowers } \\
\text { Cloves (whole fruit,cloves \& stems) } \\
\text { Nutmeg,mace \& cardamons } \\
\text { Seeds of anise,badian,fennel,coriander,cumin et } \\
\text { Thyme,saffron,bay leaves \& other spices }\end{array}$ \\
\hline 08 & Feed. Stuff for animals excl. Unmilled & Oil seed cake \& meal \& other veg. Oil residues \\
\hline 09 & Miscellaneous food preparations & Other miscellaneous food preparations \\
\hline 11 & Beverages & $\begin{array}{l}\text { Cider \& fermented beverages, nes } \\
\text { Beer including ale,stout, porter } \\
\text { Distilled alcoholic beverages } \\
\text { Grap must,in fermantation or with }\end{array}$ \\
\hline
\end{tabular}


Wine of fresh grapes, grape must

Vermouths \& other wines of fresh grapes

\begin{tabular}{|c|c|c|}
\hline 12 & Tobacco & Tobacco, unmanufactured \& scrap \\
\hline 21 & Hides, skins and fur skins, undressed & $\begin{array}{l}\text { Bovine \& equine hides excl. Calf \& kip skins } \\
\text { Calf skins and kip skins } \\
\text { Goat skins and kid skins } \\
\text { Sheep and lamb skins, with the wool on } \\
\text { Sheep and lamb skins, without the wool }\end{array}$ \\
\hline 22 & Oil seeds, oil nuts and oil kernels & $\begin{array}{l}\text { Groundnuts peanuts green, ex.flour and meal } \\
\text { Copra, ex.flour and meal } \\
\text { Palm nuts \& kernels } \\
\text { Soya beans } \\
\text { Linseed } \\
\text { Cotton seed } \\
\text { Castor oil seed } \\
\text { Oil seeds,oil nuts \& oil kernels, nes } \\
\text { Flour \& meal of oil seeds,nuts,kernels, fat }\end{array}$ \\
\hline 26 & Textile fibres, not manufactured, and & $\begin{array}{l}\text { Raw cotton, other than linters } \\
\text { Cotton linters } \\
\text { Cotton waste, not carded or combed } \\
\text { Cotton,carded or combed } \\
\text { Jute \& waste } \\
\text { Flax and flax tow and waste } \\
\text { True hemp and true hemp tow and waste } \\
\text { Sisal and other fibres of the agave family } \\
\text { Manila fibre and manila tow and waste } \\
\text { Vegetable textile fibres, nes and waste } \\
\text { Horsehair \& other coarse hair,not }\end{array}$ \\
\hline 29 & Crude animal and vegetable materials, nes & Bristles and brush making hair \& their wastes \\
\hline 42 & Fixed vegetable oils and fats & $\begin{array}{l}\text { Soya bean oil } \\
\text { Cotton seed oil } \\
\text { Groundnut /peanut/ oil } \\
\text { Olive oil } \\
\text { Sunflower seed oil } \\
\text { Rape,colza and mustard oils } \\
\text { Linseed oil } \\
\text { Palm oil } \\
\text { Coconut copra oil } \\
\text { Palm kernel oil } \\
\text { Castor oil } \\
\text { Fixed vegetable oils,nes }\end{array}$ \\
\hline 51 & Chemical elements and compounds & Sugars,chem.pure excl.sucrose glucose lactose \\
\hline 59 & Chemical materials and products, nes & $\begin{array}{l}\text { Starches and inulin } \\
\text { Gluten and gluten flour }\end{array}$ \\
\hline 61 & Leather, Ithr. Manufs., nes \& dressed fur & $\begin{array}{l}\text { Calf leather } \\
\text { Leather of other bovine cattle \& equine leather } \\
\text { Leather of sheep and lamb skins } \\
\text { Leather of goat and kid skins } \\
\text { Other leather }\end{array}$ \\
\hline
\end{tabular}

\section{List of countries}

Albania, Algeria, Argentina, Australia, Austria, Barbados, Belgium, Bolivia, Brazil, Bulgaria, Cameroon, Canada, Central African Republic, Chile, China, Colombia, Costa Rica, Croatia, Denmark, Ecuador, Egypt, El Salvador, Finland, Former Czechoslovakia, Former USSR, Former Yugoslavia, France, Germany, Greece, Guatemala, Honduras, Hungary, Iceland, India, Indonesia, Ireland, Israel, Italy, Japan, Jordan, Luxembourg, 
Madagascar, Malawi, Malaysia, Malta, Mexico, Morocco, Netherlands, New Zealand, Nicaragua, Nigeria, Norway, Pakistan, Paraguay, Peru, Philippines, Poland, Portugal, Republic of Korea, Romania, Senegal, Singapore, Slovenia, Spain, Sri Lanka, Sudan, Sweden, Switzerland, Thailand, Togo, Trinidad and Tobago, Tunisia, Turkey, United Kingdom, Uruguay, USA, Venezuela. 